This PDF is a selection from an out-of-print volume from the National Bureau of Economic Research

Volume Title: International Capital Flows

Volume Author/Editor: Martin Feldstein, editor

Volume Publisher: University of Chicago Press

Volume ISBN: 0-226-24103-3

Volume URL: http://www.nber.org/books/feld99-2

Publication Date: January 1999

Chapter Title: Capital Flows to Latin America

Chapter Author: Sebastian Edwards, Francisco Gil Diaz, Arminio Fraga

Chapter URL: http://www.nber.org/chapters/c9796

Chapter pages in book: (p. 5 - 56) 


\section{1 \\ Capital Flows to Latin America}

\section{Sebastian Edwards \\ 2. Francisco Gil Diaz \\ 3. Arminio Fraga}

\section{Sebastian Edwards}

\section{Capital Inflows into Latin America: A Stop-Go Story?}

\subsubsection{Introduction}

During the late 1980s and early 1990s the vast majority of the Latin American countries embarked on ambitious reforms aimed at modernizing their economies. Country after country turned away from decades of protectionism and government controls and began to experiment with market-oriented policies. Colombia provides a vivid illustration of this regional trend. During the early months of 1990 candidate César Gaviria promised that, if elected president, he would launch a major transformation of Colombia's economic system. In every speech he argued that the development path followed by Colombia since the 1940s had become obsolete and that, in order to achieve rapid growth and improve social conditions for the majority of the population, significant reforms had to be undertaken; he called for a major shake-up of the Colombian economy. On 7 August 1990 Cêsar Gaviria was inaugurated as Colombia's constitutional president. During the next four years a set of policies aimed at drastically changing the nature of Colombia's economic structure were put into effect: exchange controls were abolished; imports were liberalized; labor legislation was reformed; controls over direct foreign investment were relaxed; the financial sector was deregulated; legislation governing port operations was modified; the insurance industry was liberalized; and the tax system was mod- 
ernized. This phenomenon was not unique to Colombia, however. Close to Colombia, the administrations of Presidents Fujimori in Peru, Perez in Venezuela, and Sanchez de Losada in Bolivia also embarked on major reform efforts. In other countries a similar trend was followed: Presidents Menem in Argentina, Cardoso in Brazil, and Arzu in Guatemala, among others, also launched important modernization programs during the 1990s. It is not an exaggeration to say that during the first half of this decade most countries in Latin America followed the steps of the two early reformers: Chile and Mexico. ${ }^{1}$

And when the world was about to believe that Latin America had finally changed, the Mexican currency crisis erupted in December 1994. This turn of events generated considerable anxiety among policy analysts, financial operators, and international civil servants. Some asked whether Latin America was indeed ready to adopt market-oriented policies, while others questioned the appropriateness of specific policies, including the use of a rigid nominal exchange rate as a way to reduce inflation. The role played by large capital inflows - which at their peak surpassed 9 percent of Mexico's GDP-has been at the center of almost every postmortem of the Mexican crisis. Some analysts have argued that these massive flows allowed Mexico to increase consumption in spite of weak fundamentals. According to others, the predominantly "speculative" nature of these flows signaled, from early on, that the Mexican experience was bound to run into a serious external crisis. Yet others argued that Mexico's mistake was to have lifted capital controls too early, allowing these speculative flows to disturb the country's macroeconomic foundations. According to these analysts a more appropriate policy stance in Mexico would have been to maintain some form of capital controls, as a number of emerging economies - including Chile, Colombia, and Israel-have done for some time. The proponents of this view argue that capital controls isolate these young economies from volatile short-run capital flows, helping them to reduce their overall degree of vulnerability to external shocks, including speculative attacks. ${ }^{2}$

In the early 1990s it became fashionable to compare Latin America's somewhat traumatic experience with capital inflows with East Asia's supposedly successful capital flow management. The recent currency crises in a number of East Asian countries-including Thailand, Malaysia, the Philippines, Indonesia, and South Korea-have raised, once again, analysts' interest in issues related to the management of capital flows. Questions related to capital account sustainability and the feasibility of fixed nominal exchange rates in a world of capital mobility, among others, have moved to the fore of policy discussions. It may be tempting to argue that Latin America and East Asia are not so different after all. Perhaps it was a matter of timing, with the Mexican crisis leading the way to the more recent developments in East Asia. Moreover, the volatility

1. On the Latin American reforms see, e.g., Edwards (1995b).

2. On the Mexican crisis see, e.g., Dornbusch and Werner (1994), Dornbusch, Goldfajn, and Valdes (1995), Bruno (1995), and Calvo and Mendoza (1996). On the benefits and costs of capital controls see, e.g., the essays collected in Edwards (1995a). 
experienced by financial markets during the fall of 1997 has raised the question of "contagion." Analysts have wondered whether in an era of capital mobility rumors and changes in expectations in a particular country can spread to other nations with healthy fundamentals.

This paper deals with Latin America's experience with capital flows during the past decade and a half. It concentrates on a number of issues of increasing interest among academics and international observers, including the effect of capital inflows on domestic savings, the effect of capital mobility on the ability to engage in independent monetary policy, and the effectiveness of capital controls. Latin America's experience with capital mobility should be illuminating to scholars interested in other regions of the world. Indeed, as will be seen in this paper, during the past few years the Latin American countries have been a laboratory of sorts, where almost every possible approach to capital mobility has been tried. The paper is organized as follows: section 1.1.1 is the introduction and provides the motivation. Section 1.1.2 reviews the behavior of capital flows to Latin America during the past twenty years. It is shown that during this period the region has gone through wild cycles. In the mid- to late 1970s the countries of Latin America were on the receiving end of petrodollar recycling and were flooded with private capital. All of this came to an end with the eruption of the Mexican debt crisis in 1982. During the next eight years the international capital market dried up for every country in the region, and net private capital inflows became significantly negative. Things changed in 1991, when once again private capital began to pour into the region. In this section I also discuss the most important causes of the surge of capital flows into the area experienced during 1996-97.

In section 1.1.3 I discuss the extent to which capital mobility has been truly restricted in Latin America. I argue that in most developing countries there are significant differences between the degrees of legal capital mobility and of "true" capital mobility, and I provide some estimates of the latter. Section 1.1.4 concentrates on the effects of capital mobility on real exchange rates and international competitiveness. In this section I also address the important question of capital flow sustainability and the dynamics of adjustment, and I briefly discuss issues related to the sequencing of economic reform. Section 1.1.5 concentrates on the effectiveness of monetary policy when there is (some) capital mobility. In particular, I discuss Latin America's experiences with policies aimed at sterilizing capital flows. In this section I also address the role of capital controls as a device for isolating emerging economies from the volatility of international capital markets. I review the experiences of Chile and Colombia, and $I$ argue that, by and large, the effectiveness of capital controls has been limited in these two countries. In section 1.1.6 I deal with the role of the banking sector in intermediating capital flows in Latin American countries. Finally, in section 1.1.7 I present some concluding remarks.

It is important to stress at the outset that Latin America is an extremely diverse region with sophisticated as well as backward economies, with large 
and very small countries, with stable and volatile economic systems. This variation means that broad generalizations are bound to be misleading and to provide oversimplified views of the region. For this reason, then, in this paper I make an effort to make distinctions among countries, as well as to discuss broad regional trends.

\subsubsection{Capital Flows to Latin America: Historical Background and Recent Trends}

\section{From Petrodollar Recycling to the Mexican Debt Crisis of 1982}

During the 1960s and early 1970s Latin America was basically cut off from private international financial markets. With the exception of limited amounts of direct foreign investment (DFI), very little private capital moved into the region. During most of this period Latin America relied on official capital flows-largely from the World Bank, the Inter American Development Bank (IDB), and the International Monetary Fund (IMF). In a way the region was a captive customer of the multilateral institutions. In the mid- and late 1970s, however, things began to change as international private liquidity increased significantly, and Latin America became a major recipient of recycled "petrodollars." In 1981 alone the region received (net) private capital inflows in excess of 21 percent of exports. Individual country cases, however, differed significantly during this period. While in Brazil, Mexico, and Venezuela a majority of these flows were captured by the government and were used to finance large (and increasing) fiscal deficits, in Argentina and Chile-two nations embarked at the time on early market-oriented reforms - they were largely channeled to the private sector. ${ }^{3}$

By 1981 casual observers of the Latin American scene were surprised by how smoothly things were going. In spite of major commodity price shocks, most countries in the region continued to grow at healthy if not spectacular rates, and a handful in the Southern Cone were even experimenting with market-oriented reforms. What most observers missed at the time - as they would again a dozen years later in Mexico-were four worrisome developments: (1) real exchange rates had appreciated significantly, seriously hurting export competitiveness; (2) domestic saving remained flat, at rates inconsistent with sustainable rapid growth; (3) a large proportion of the capital inflows were being used to finance consumption or investment projects of doubtful quality; and (4) most capital inflows were intermediated by banks that were subject to little supervision, and that lack of oversight quickly became the Achilles' heel of these economies. ${ }^{4}$

3. On the behavior of the Latin American economies during this period see, e.g., Dornbusch (1988) and Edwards (1988b).

4. Naturally, since funds are fungible it is very difficult to know exactly how the capital inflows were finally used. The above description, however, gives an accurate picture of the economic developments in the region at that time. 
And to make things even worse, during that period productivity growth was extremely low in most of the region.

In August 1982 Mexico informed a stunned international community that it was not able to meet its financial obligations and that it was seeking IMF support and the postponement of its debt payments. The financial community reacted badly to this news, and with traditional herd instinct decided to pull out of Latin America as a region. In late 1982 and early 1983, country after country saw its access to international financial capital markets disappear. Even Chile and Colombia, two countries that obeyed the rules of the game and did not attempt to reschedule their debts, experienced a drying-up of private international financing. They were subject to what Ocampo (1989) has called the Latin "neighborhood effect."

From Muddling Through to the Brady Plan

Between 1982 and 1989 most of the Latin American nations muddled through, while they tried to negotiate debt reduction deals with their private creditors. The initial reaction by the creditor countries was that the debt crisis represented a temporary liquidity problem that could be solved with a combination of macroeconomic adjustment, debt-rescheduling agreements, and some structural reforms. This approach was pushed by the U.S. government and, in practice, was coordinated by the IMF and the World Bank. The official approach called for "new monies" (up to US\$20 billion) to be lent to those countries that indeed engaged in structural reforms. Not surprisingly, the banking community endorsed this view, although it argued for shifting the burden of new financing to multilateral and official institutions: "Realism demands an increased share of new money to be furnished by official sources during the next several years" (Morgan Guaranty 1987, 2). Debt-restructuring operationsIMF-sponsored programs and World Bank structural adjustment loans-were the most important elements of the early official strategy.

The 1984 issues of the IMF's World Economic Outlook and the World Bank's World Development Report included optimistic projections, predicting a steady decline of the debt-export ratio in the Latin American countries until 1990. Things, however, did not work as expected, and in the following years a growing number of analysts came to recognize that the magnitude of the problem had been seriously underestimated. By 1987 it was becoming increasingly clear that the debt burden had greatly reduced the incentives for reforming the region's economies and was seriously affecting the ability of the debtor nations to grow. Between 1985 and 1987 net resource transfers-defined as net capital inflows minus interest and dividend payments to the rest of the world-were significantly negative, averaging almost 28 percent of exports.

In March 1989 a fundamental breakthrough in the official approach toward the debt crisis took place, when the creditor nations and the multilateral institutions recognized that, in many cases, it was in everyone's interest to provide (some) debt forgiveness. The basic idea was that, for countries facing a very 
high implicit marginal tax on foreign exchange earnings, partial forgiveness of the debt would be equivalent to lowering the implicit tax and thus would encourage the type of market-oriented reform conducive to higher exports and faster growth. In March of that year U.S. secretary of the treasury Nicholas Brady announced a new initiative based on voluntary debt reduction. This basic proposal amounted to exchanging old debt for new long-term debt, with a lower face value. The exact conversion ratios, and the detailed characteristics of the new instruments, were to be negotiated between the debtor countries and their creditors. In order to make this new approach feasible and attractive to creditor banks, the advanced nations and the multilateral institutions devoted substantial resources - on the order of US $\$ 30$ billion - to guarantee the new "Brady" concessional bonds. Typically, principal payments on these new securities were backed by thirty-year zero-coupon U.S. Treasury bills, and interest payments were subject to rolling three-year guarantees.

Starting in 1989, then, the official approach toward the crisis combined two basic mechanisms for alleviating the debt burden. First, the use of debt reduction schemes based on secondary market operations was actively encouraged. Although this technique for reducing the debt had been used since the mid1980 s, it acquired special momentum after 1988, when, in a number of countries, debt-equity swaps became an important mode for privatizing state-owned enterprises. Second, direct debt reduction agreements between creditors (commercial banks) and individual countries became increasingly common after the introduction of the Brady plan. Between 1989 and 1997 Costa Rica, Mexico, Venezuela, Uruguay, Argentina, Brazil, and Peru reached agreements with their creditors to reduce their debt burdens.

In order for countries to be eligible for Brady plan negotiations they had to show willingness "plus some prior action" to engage in serious marketoriented economic reform. From an incentive point of view this new initiative was intended to have two effects. First, it was seen as a way of rewarding countries truly committed to implementing modernization reforms, and second, it was expected that in some countries it would lift the debt overhang burdens associated with extremely high payments. In 1989 Mexico and Costa Rica were the first countries that, within the Brady plan framework, reached broad agreements with their creditors to reduce the value of their debts. Venezuela and Uruguay followed in 1990 and 1991, and Argentina and Brazil signed draft agreements in 1992. In 1996 Peru became the latest country to come to terms with its creditors within the context of the Brady plan. Table 1.1 contains the details of selected Brady deals.

By 1990 the vast majority of the countries in the region had embarked on market-oriented reforms. Although programs varied across countries, they exhibited three common components: (1) Stabilization programs were implemented aimed at reducing inflation and generating a sustainable current account balance. In most countries fiscal retrenchment, including major tax reform, was at the heart of these programs. (2) Economies were opened to 


\begin{tabular}{|c|c|c|c|c|c|c|}
\hline $\begin{array}{l}\text { Country and Date } \\
\text { of Agreement }\end{array}$ & $\begin{array}{l}\text { Face Value of } \\
\text { Eligible Debt }\end{array}$ & Buyback $^{a}$ & $\begin{array}{l}\text { Discounted } \\
\text { Bonds }^{\mathrm{a}}\end{array}$ & Par Bonds ${ }^{b}$ & New Money ${ }^{\mathbf{b}}$ & $\begin{array}{c}\text { Total Debt, } \\
\text { December } 1991^{\circ}\end{array}$ \\
\hline Argentina, 1993 & $23,160^{d}$ & n.a. & $\begin{array}{l}\text { n.a. } \\
(35)\end{array}$ & $\begin{array}{l}\text { n.a. } \\
(35)\end{array}$ & $\begin{array}{c}0 \\
(4-6)^{\mathfrak{e}}\end{array}$ & 56,273 \\
\hline Brazil, 1993 & $44,000^{\mathrm{f}}$ & 0 & $\begin{array}{l}\text { n.a. } \\
(35)\end{array}$ & n.a.g & n.a..$^{g}$ & 118,148 \\
\hline Mexico, 1989 & 48,089 & 0 & $\begin{array}{r}20,851 \\
(35)\end{array}$ & $\begin{array}{r}22,427 \\
(6.25)\end{array}$ & $\begin{array}{r}4,387 \\
(\text { LIBOR }+13 / 16)\end{array}$ & 98,263 \\
\hline Venezuela, 1990 & 19,098 & $\begin{array}{l}1,411 \\
(55)\end{array}$ & $\begin{array}{l}1,794 \\
(30)\end{array}$ & $\begin{array}{r}10,333 \\
(6.75)\end{array}$ & $\begin{array}{r}6,060 \\
(\text { LIBOR }+7 / 8)\end{array}$ & 34,081 \\
\hline
\end{tabular}

Source: World Bank, several country-specific reports.

Note: n.a. $=$ not available.

${ }^{a}$ Numbers in parentheses are percentage discounts.

'Numbers in parentheses are interest rates.

'Includes IMF and net short-term debt.

${ }^{d}$ Estimated. In addition, there are $\$ 8.6$ billion in arrears, including imputed interest.

'Interest rate increases from 4 percent in the first year to 6 percent in the seventh year; 6 percent from then on.

'Estimated. In addition, there are $\$ 6$ billion in arrears, including imputed interest.

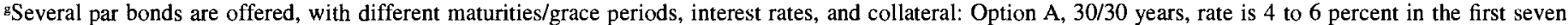
years, 6 percent from then on, full collateral principal, twelve-month interest. Option B, 15/9 years, rate is 4 to 5 percent in the first six years, LIBOR $+13 / 16$ from then on, twelve-month interest collateral for six years. Option C, 20/10 years, LIBOR $+13 / 16$, but interest above the rate in bond B is capitalized, no collateral. Option D, 20/10 years, 8 percent and interest above the rate in bond B is capitalized, no collateral. Option E, 18/10 years, LIBOR + 7/8, no collateral; under option $\mathrm{E}$, new money is equivalent to 18.18 percent of debt tendered for debt conversion bonds. 


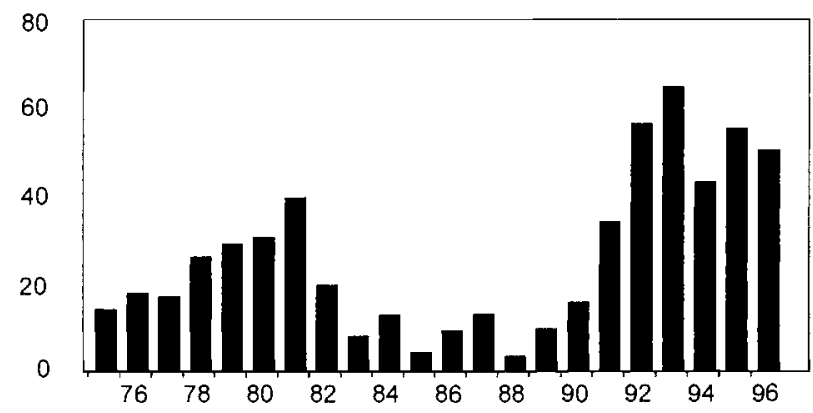

Fig. 1.1 Total capital inflows to Latin America, 1975-96 (billions of U.S. dollars)

international competition. While every country reduced its trade barriers substantially, the approaches to capital account liberalization were very diverse. In some nations, Mexico and Argentina for example, capital controls were abolished; in others, such as Brazil, Chile, and Colombia, some forms of capital controls were maintained. (3) Major privatization and deregulation programs were undertaken aimed at reducing the importance of the state in economic affairs. As the reforms proceeded, many countries added the implementation of social programs benefiting the poor as a fourth component of the new development strategy (Edwards 1995b).

The Resumption of Private Flows: Magnitudes and Some Issues

Starting in 1991 the majority of the Latin American countries were able, once again, to attract private capital. By 1992 the net volume of funds had become so large-exceeding 35 percent of the region's exports-that a number of analysts began to talk about Latin America's "capital inflow problem" (Calvo, Leiderman, and Reinhart 1993; Edwards 1993). To many analysts this sudden change from capital scarcity and negative resource transfers to foreign capital overabundance was surprising and reflected a surge in speculation in international markets. To others the fact that merely a dozen years after a major crisis these countries were able to tap the international market reflected the success of the market-oriented reforms. If the market is willing to reward these countries with plentiful funds, the argument went, it must mean that the reforms are bearing fruit.

Figure 1.1 presents the evolution of net total capital flows (in billions of dollars) to Latin America during the period 1975-96. Figure 1.2 presents data on net resource transfers as a percentage of exports for the same period. Finally, figure 1.3 presents the evolution of net official capital inflows as a percentage of exports during 1980-96. Several interesting aspects of the Latin American experience emerge from these figures. First, the cyclical-almost paranoid, one could say-nature of capital inflows to Latin America comes out clearly. Figure 1.1 shows the abundance of the late 1970 s and early 1980 s, the 


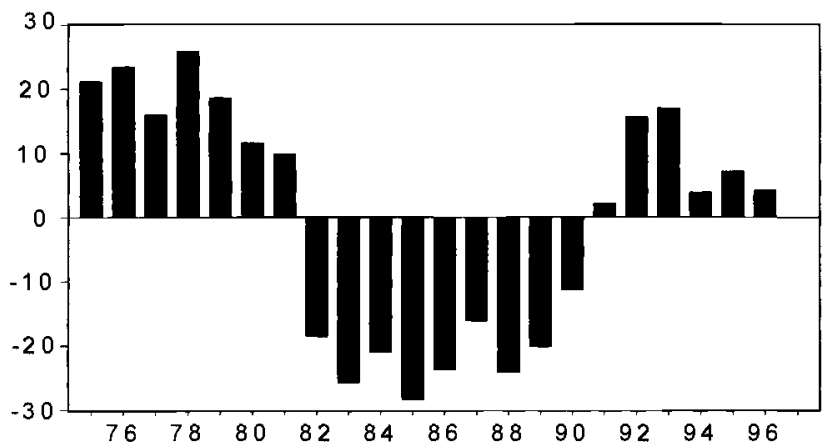

Fig. 1.2 Net resource transfers to Latin America as percentage of exports, 1975-96

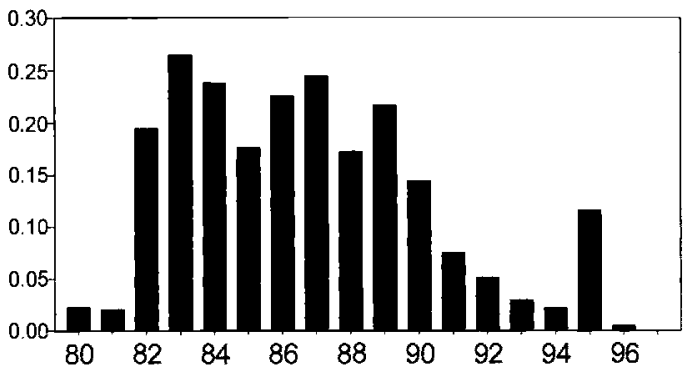

Fig. 1.3 Net official capital inflows as percentage of exports, 1980-96

following collapse in inflows during most of the $1980 \mathrm{~s}$, and the remarkable return to abundance in recent years. Figure 1.2 shows the severity of the crunch in the 1980s, when the region as a whole was transferring (in net terms) almost 30 percent of its exports to the rest of the world. And the data in figure 1.3 show a new reality in the $1990 \mathrm{~s}$, when official capital flows-and in particular funds coming from such multilateral institutions as the IMF and the World Bank - have declined significantly in relative terms. Notice, however, that this figure shows a large jump in net official flows in 1995, when in response to the Mexican crisis, the IMF, the World bank, the IDB, and the U.S. government transferred large amounts of funds to Mexico. This picture is a vivid reflection of the significant change in the role of official financing during the past few years. It has gone from being the most important provider - and in some countries the sole provider-of foreign funds to being a provider of stabilizing funds. The multilateral official institutions have become insurance companies of sorts, whose main role is providing relief when a disaster occurs.

Figure 1.4 presents data on net capital inflows for eight selected countries. Figure 1.5 contains data on the composition of capital inflows to these Latin 

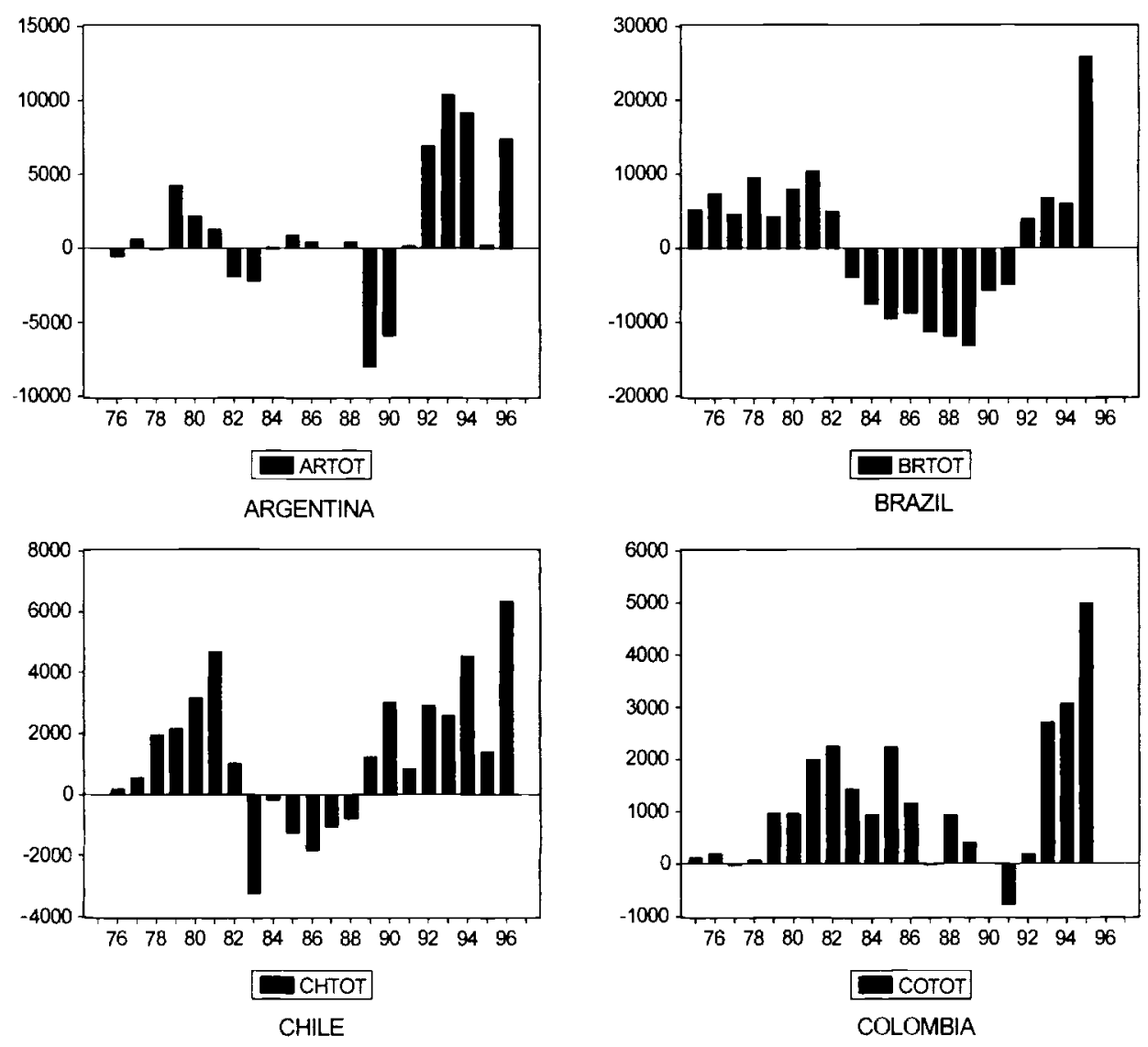

Fig. 1.4 Total net capital flows to selected Latin American countries, 1975-96 (millions of U.S. dollars)

American countries for 1975-96. Three types of flows are distinguished: (1) $D F I$ - these flows reflect, at least in principle, a long-term commitment on the part of the investor in the host country. (2) Portfolio investment-this category includes transactions in equity and debt securities. (3) Other types of flows - this rather broad category includes trade credit (both long and short term) and official (bilateral and multilateral) loans. Several important trends emerge from these figures. First, portfolio investment is a relatively new phenomenon in these countries. Until the late 1980 s "other" constituted the dominant form of inflow to most countries. Second, in some countries portfolio flows were by far the dominant form of inflow after 1991. This has been particularly the case in Argentina and Mexico. Figure 1.5 also shows that Brazil has experienced a tremendous surge in portfolio funds in the past few years. These portfolio flows take two basic forms: equity acquisitions - mostly in the form 

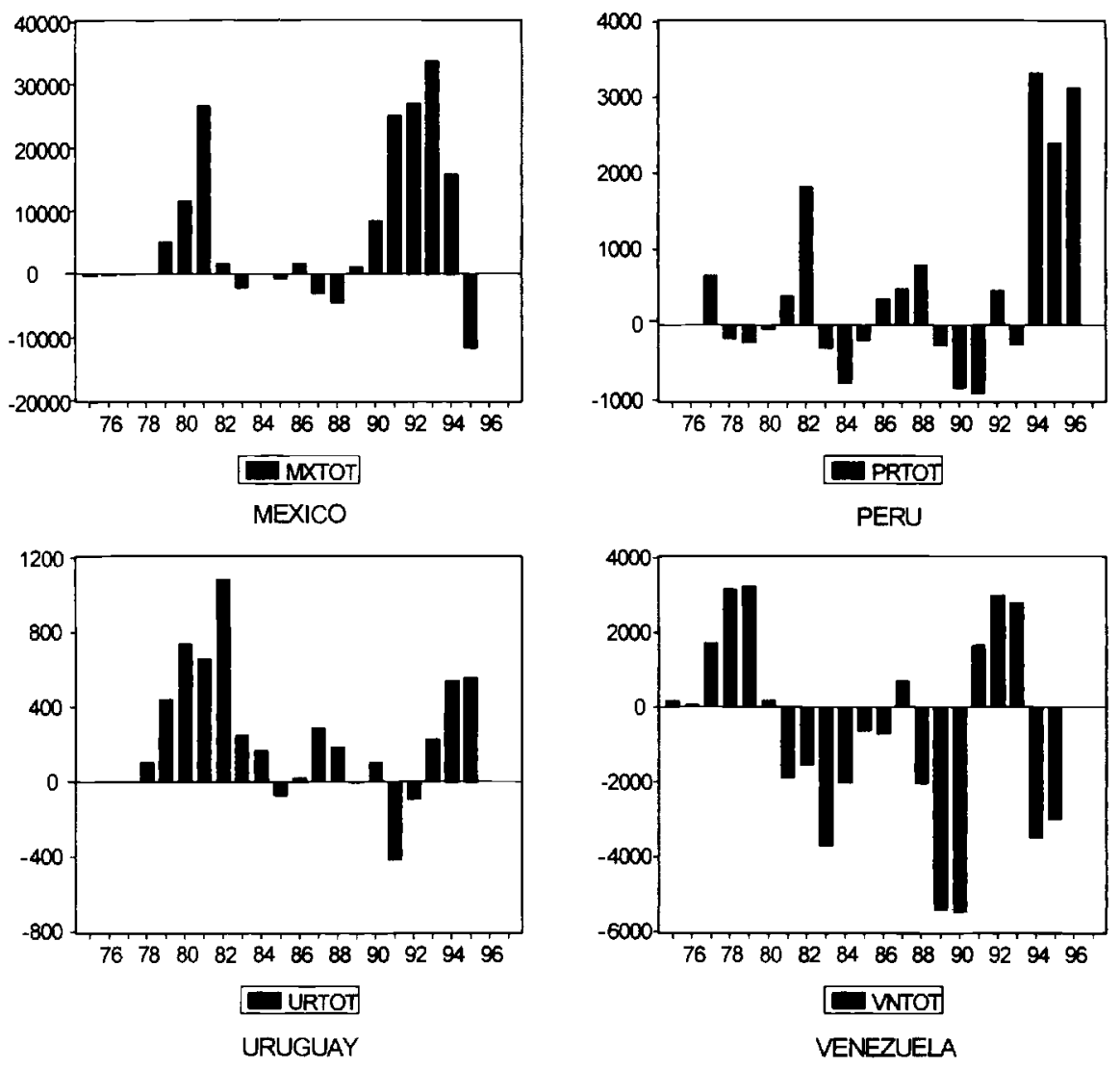

Fig. 1.4 (cont.)

of American Depository Receipts (ADRs) - by foreign investors and bond issues in international markets. The World Bank (1997) has reported that an increasing number of institutional investors (including pension funds) in the advanced countries are adding emerging economy equities to their portfolios. This heavy reliance on equities and bonds contrasts with the 1970s, when syndicated bank loans constituted the dominant form of private capital inflow to Latin America. Third, figure 1.5 shows that the importance of DFI varies greatly across countries. Chile, Colombia, and Peru have received particularly large volumes of DFI in the past few years. In all three cases these funds have been largely devoted to natural-resource-intensive sectors-mining in Chile and Peru and oil in Colombia.

The recent surge in capital inflows - and particularly in portfolio inflowsto Latin America has been the result of two basic forces: First, developments in international financial conditions, and in particular the decline in U.S. inter- 


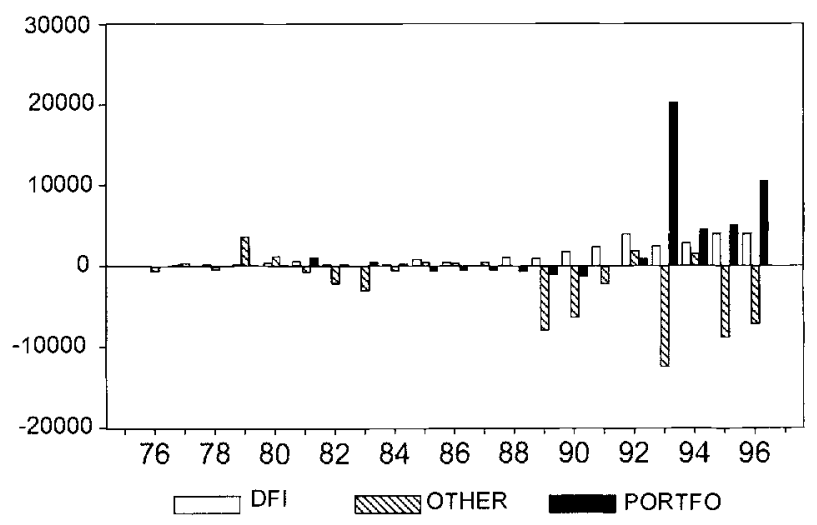

ARGENTINA

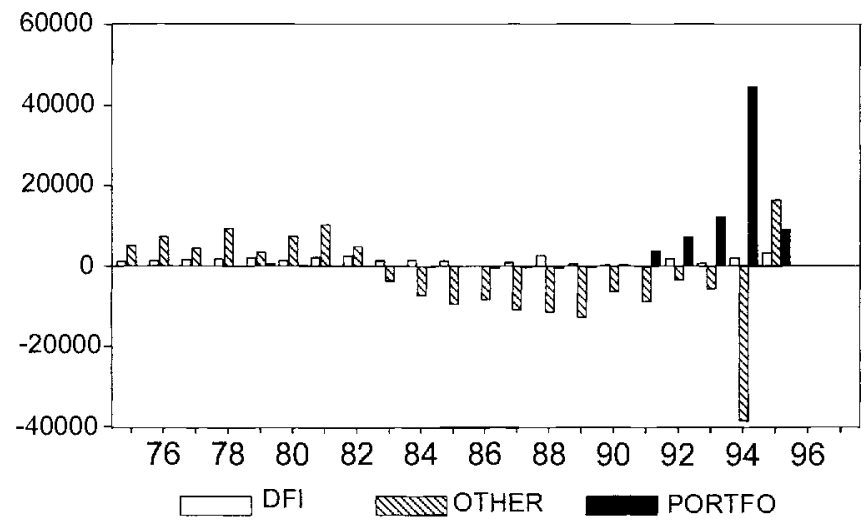

BRAZIL

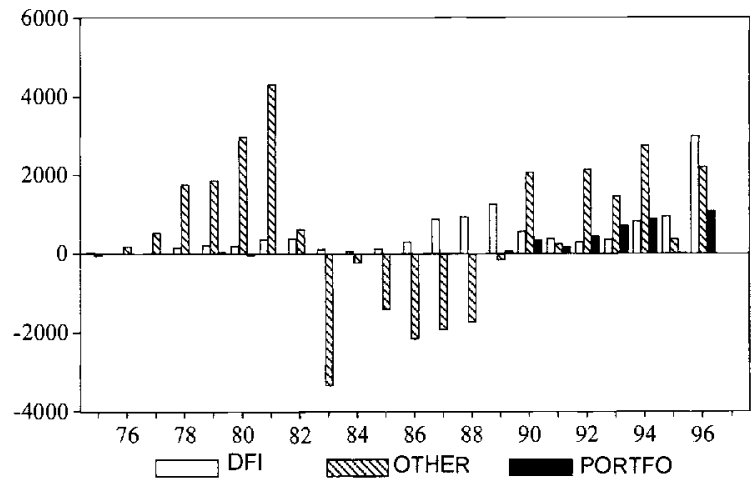

CHILE

Fig. 1.5 Composition of capital flows to selected Latin American countries, 1975-96 (millions of U.S. dollars) 

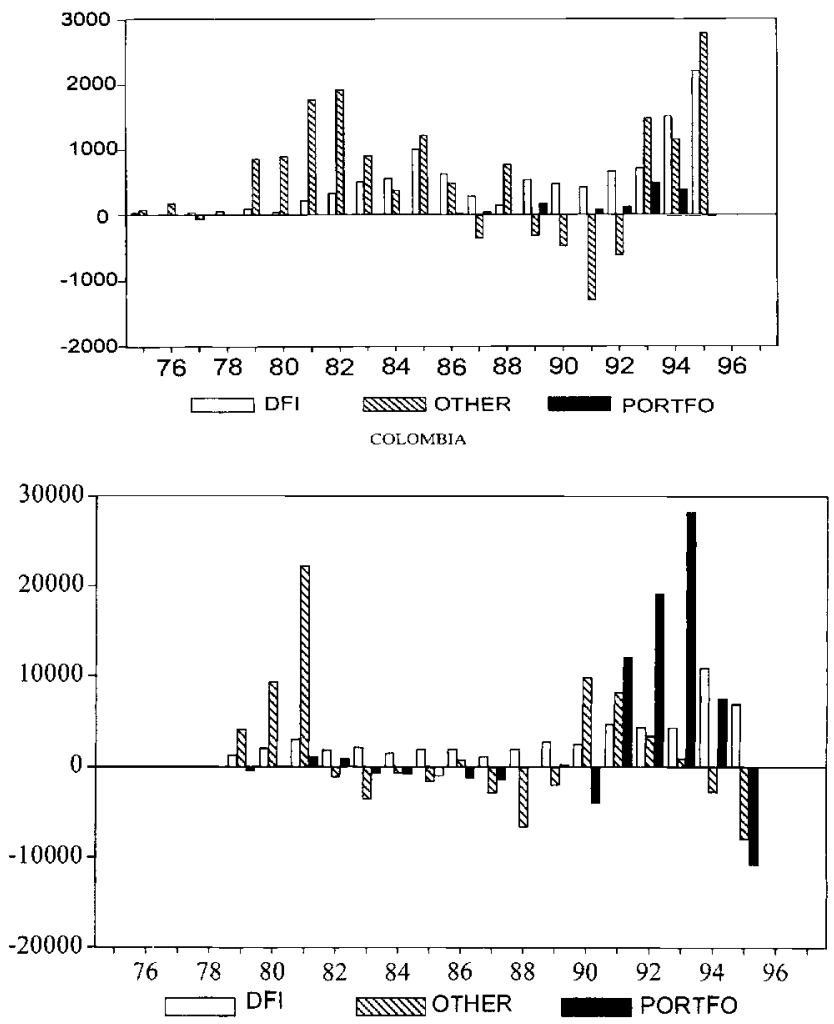

MEXICO

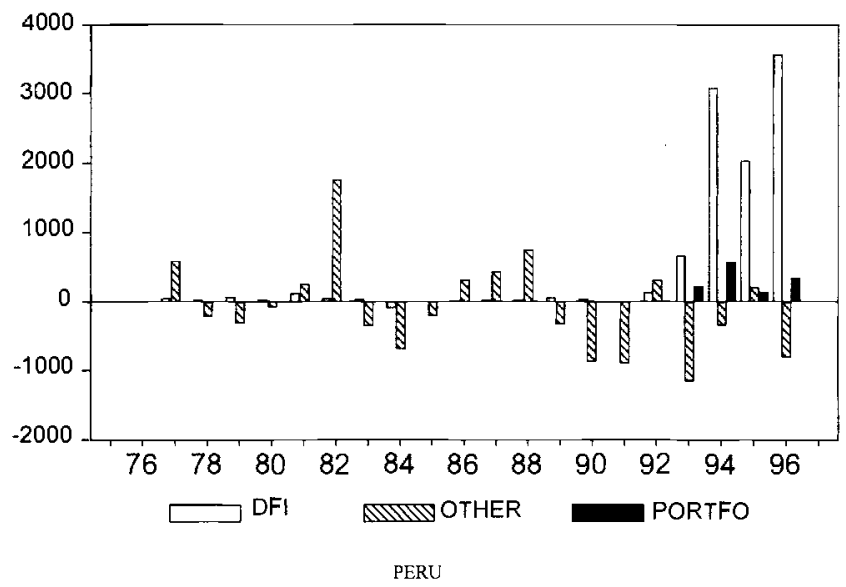

Fig. 1.5 (cont.) 

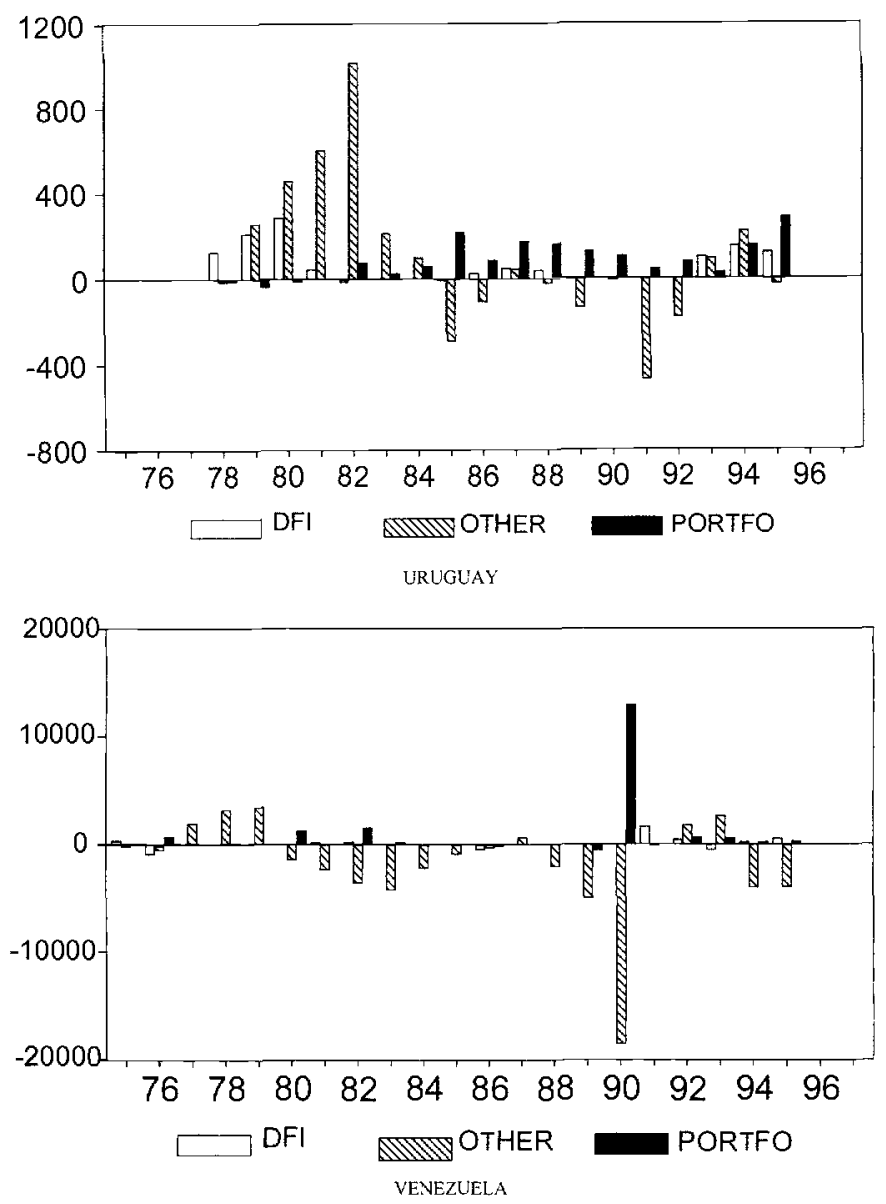

Fig. 1.5 Composition of capital flows to selected Latin American countries, 1975-96 (millions of U.S. dollars) (cont.)

est rates since 1990-91, have encouraged investors in the advanced countries to seek higher returns in other markets, including Latin America. Calvo et al. (1993) provided an early, and very influential, study of the determinants of capital inflows to the region. These authors argue that cyclical external factors have been by far the most important determinants of these flows. These results have recently been confirmed by the World Bank's (1997) massive study of private capital inflows to developing countries. Second, the improvement in Latin America's economic prospects-including the reduction in country risk that has been associated with the implementation of market-oriented reforms - has increased the attractiveness of these countries to international investors. In an extension of the Calvo et al. (1993) study, Chuhan, Claessens, 
and Mamingi (1993) found that the recipient country's own fundamentals were as important as cyclical factors in explaining the surge in portfolio flows to Latin America. In a recent analysis of the determinants of capital inflows to Chile, Larrain, Laban, and Chumacero (1997) argued that, while interest rate differentials play a key role in determining short-term flows, they are unimportant in determining longer term ones. Long-term flows to Chile are affected by longer term structural variables, and in particular by the country's impressive market-oriented reforms.

The prominent role played by external cyclical factors suggests that, once external conditions change, there may be massive flow reversals. Although it is too early to know whether this will indeed be the case, some evidence already indicates that flow volatility has declined somewhat. First, quarterly inflows to the large countries are far less variable than in the past. For example, for the 1980 s the coefficients of variation of quarterly aggregate net inflows to Argentina, Brazil, and Mexico were 5.4, 3.1, and 9.3, respectively. For 1990-97 these coefficients had declined in all three countries, to 2.1, 2.6, and 1.3. Second, it seems that the extent of cross-market contagion has declined significantly. This was apparent in the aftermath of the Mexican and Brazilian currency crises of 1994 and 1999, when in stark contrast with previous episodes-including the debt crisis of 1982 - the international financial community did not stampede out of Latin America. In fact, this time around, international investors were quick to realize that there are significant differences among Latin American countries, and after a brief hesitation, they even increased their exposure in those countries with strong fundamentals. Both of these developments suggest, then, that in spite of the importance of cyclical elements in determining the direction of capital flows, countries with strong fundamentals-including modern bank supervisory systems - will not face imminent collapse once international financial conditions change.

In recent years a number of analysts have become concerned about the very low level of saving in the region: on average, Latin America saves 19 percent of GDP, compared with 32 percent in East Asia (see Edwards 1996). This concern has grown after the Mexican peso crisis of 1994. The surge in capital inflows experienced by Mexico in 1991-94 allowed Mexican nationals to increase their expenditure greatly. Starting in 1990, the country experienced a consumption boom that put additional pressure on an already appreciated real exchange rate and contributed to the creation of a large current account deficit. This rapid increase in consumption had as a counterpart a steep decline in domestic saving, from almost 20 percent of GDP in 1988 to 16 percent of GDP in 1993. In the 1993 Trends in Developing Economies, the World Bank staff already expressed its apprehension in vivid terms and stated that "in 1992 about two-thirds of the widening of the current account deficit can be ascribed to lower private savings. ... If this trend continues, it could renew fears about Mexico's inability to generate enough foreign exchange to service debt or remit dividends" (330). After 1993 the decline in saving became more serious, as 
fiscal policy was relaxed somewhat. The extent to which capital inflows-or more specifically the accompanying current account deficits-crowd out domestic saving has long been a subject of inquiry among authors interested in understanding saving behavior. In a recent study of saving in Latin America Edwards (1996) found that an increase in the current account deficit of 1 percent of GDP is associated with a decline in private saving of only 0.2 percent of GDP. Interestingly enough, however, these results suggest that in Latin America higher current account deficits have a somewhat greater crowdingout effect on public sector saving.

\subsubsection{The "True" Degree of Capital Mobility in Latin America}

For many years most Latin American countries restricted international capital mobility through a variety of means, including taxes, administrative controls, and outright prohibitions. Legally speaking, then, and as the IMF documented year after year, most countries in the region had closed capital accounts. From an economic point of view, however, what matters is not the legal degree of capital restrictions but the actual or "true" degree of capital mobility. Ample historical evidence suggests that there have been significant discrepancies between the legal and the actual degree of controls. In countries with severe impediments to capital mobility-including countries that have banned capital movement - the private sector has traditionally resorted to overinvoicing imports and underinvoicing exports to sidestep legal controls on capital flows. The massive volume of capital that fled Latin America in the wake of the 1982 debt crisis showed clearly that, when faced with "appropriate" incentives, the public can be extremely creative in finding ways to move capital internationally. A number of authors have resorted to the term "semiopen" economy to describe a situation in which the existence of taxes, licenses, or prior deposits restricts the effective freedom of capital movement. However, the questions of how to measure, from an economic point of view, the degree of capital mobility and the extent to which domestic capital markets are integrated in the world capital market are still subject to some debate.

In two early studies Harberger $(1978,1980)$ argued that the effective degree of integration of capital markets should be measured by the convergence of private rates of return to capital across countries. He used national accounts data for a number of countries -including eleven Latin American countriesto estimate rates of return to private capital and found that these were significantly similar. More important, he found that these private rates of return were independent of national capital-labor ratios. Harberger interpreted these findings as supporting the view that capital markets are significantly more integrated than a simple analysis of legal restrictions would suggest. Additionally, Harberger (1980) argued that remaining (and rather small) divergences in national rates of return to private capital are mostly the consequence of country risk premiums imposed by the international financial community on particular coun- 
tries. These premiums, in turn, are determined by the perceived probability of default and depend on a small number of "fundamentals," including the debtGDP ratio and the international reserve position of the country in question.

In trying to measure the effective degree of capital mobility, Feldstein and Horioka (1980) analyzed the behavior of saving and investment in a number of countries. They argue that, under perfect capital mobility, changes in saving and investment will be uncorrelated in a specific country. That is, in a world without capital restrictions an increase in domestic saving will tend to "leave the home country," moving to the rest of the world. Likewise, if international capital markets are fully integrated, increases in domestic investment will tend to be funded by the world at large, and not necessarily by domestic saving. Using a data set for sixteen OECD countries Feldstein and Horioka found that saving and investment ratios were highly positively correlated and concluded that these results strongly supported the presumption that long-term capital movement was subject to significant impediments. Frankel (1989) applied the Feldstein-Horioka test to a large number of countries during the 1980s, including a number of Latin American nations. His results corroborated those obtained by the original study, indicating that saving and investment have been significantly positively correlated in most countries.

In a recent comprehensive analysis of the degree of capital mobility Montiel (1994) estimated a series of Feldstein-Horioka equations for sixty-two developing countries, including fifteen Latin American nations. He argued that the estimated regression coefficient for the industrial countries should be used as a benchmark for evaluating whether a particular country's capital account is open or not. After analyzing a number of studies he concluded that a saving ratio regression coefficient of 0.6 provides an adequate benchmark: if a country regression coefficient exceeds 0.6 , it can be classified as having a "closed" capital account; if the coefficient is lower than 0.6 , the country has a rather high degree of capital mobility. Using this procedure he concluded that most Latin American nations exhibited a remarkable degree of capital mobilityindeed much larger than an analysis of legal restrictions would suggest. Table 1.2 contains the estimated Feldstein-Horioka $b$ regression coefficients reported by Montiel (1994). As may be seen, for a large number of these countries the regression coefficient is below the 0.6 cutoff level.

Although Harberger and Feldstein-Horioka used different methodologiesthe former looking at prices and the latter at quantities - they agreed on the need to go beyond legal restrictions in assessing the extent of capital mobility. In a series of studies Edwards (1985, 1988b) and Edwards and Khan (1985) argued that time series on domestic and international interest rates could be used to assess the degree of openness of the capital account (see also Montiel 1994). Using a general model that yields the closed and open economy cases as corner solutions, they estimated the economic degree of capital integration. They argued that capital restrictions play two roles: first, they introduce divergences into interest rate parity conditions, and second, they tend to slow the 

Coefficient of the Saving Ratio, 1970-90

\begin{tabular}{lcc}
\hline Country & Ordinary Least Squares & $\begin{array}{c}\text { Instrumental } \\
\text { Variables }\end{array}$ \\
\hline Argentina & $1.08^{\mathrm{a}}$ & $0.88^{\mathrm{a}}$ \\
Brazil & $0.58^{\mathrm{b}}$ & $0.27^{\mathrm{b}}$ \\
Chile & $0.51^{\mathrm{b}}$ & $0.40^{\mathrm{c}}$ \\
Colombia & 0.07 & $0.03^{\mathrm{c}}$ \\
Costa Rica & -0.28 & $0.57^{\mathrm{a}}$ \\
Dominican Republic & $0.81^{\mathrm{b}}$ & $0.51^{\mathrm{b}}$ \\
Ecuador & $0.42^{\mathrm{b}}$ & $0.73^{\mathrm{a}}$ \\
El Salvador & $0.29^{\mathrm{b}}$ & $0.50^{\mathrm{b}}$ \\
Guatemala & 0.23 & $0.54^{\mathrm{b}}$ \\
Honduras & $0.53^{\mathrm{b}}$ & $0.80^{\mathrm{a}}$ \\
Mexico & $0.28^{\mathrm{b}}$ & $0.20^{\mathrm{c}}$ \\
Paraguay & $0.52^{\mathrm{b}}$ & 0.60 \\
Peru & $0.43^{\mathrm{b}}$ & 0.53 \\
Uruguay & $1.10^{\mathrm{a}}$ & 0.58 \\
Venezuela & $0.70^{\mathrm{b}}$ & $1.88^{\mathrm{b}}$ \\
\hline
\end{tabular}

Source: Montiel (1994).

${ }^{a}$ Different from zero at the 5 percent level.

'Different from both zero and one at the 5 percent level.

'Different from one at the 5 percent level.

process of interest rate convergence. The application of this model to a number of countries (Brazil, Colombia, and Chile) confirms the result that in general the actual degree of capital mobility is greater than the legal restrictions suggest. Haque and Montiel (1991) and Reisen and Yeches (1991) expanded this model to allow the estimation of the degree of capital mobility even in cases when there are not enough data on domestic interest rates and when there are changes in the degree of capital mobility through time. Their results once again indicated that in most Latin American countries "true" capital mobility has historically exceeded "legal" capital mobility.

\subsubsection{Capital Mobility, Real Exchange Rates, and International Competitiveness}

The new growth strategy embraced by the Latin American countries since the late 1980 s is largely based on achieving export-led growth. This requires, in turn, maintaining competitive real exchange rates, that is, real exchange rates that do not become overvalued. Starting in 1991-92, however, a surge in capital inflows has allowed the Latin American countries to increase substantially aggregate expenditure, generating significant pressure toward real exchange rate appreciation and, thus, a loss of international competitiveness. This phenomenon has generated concern among academics, policymakers, and fi- 

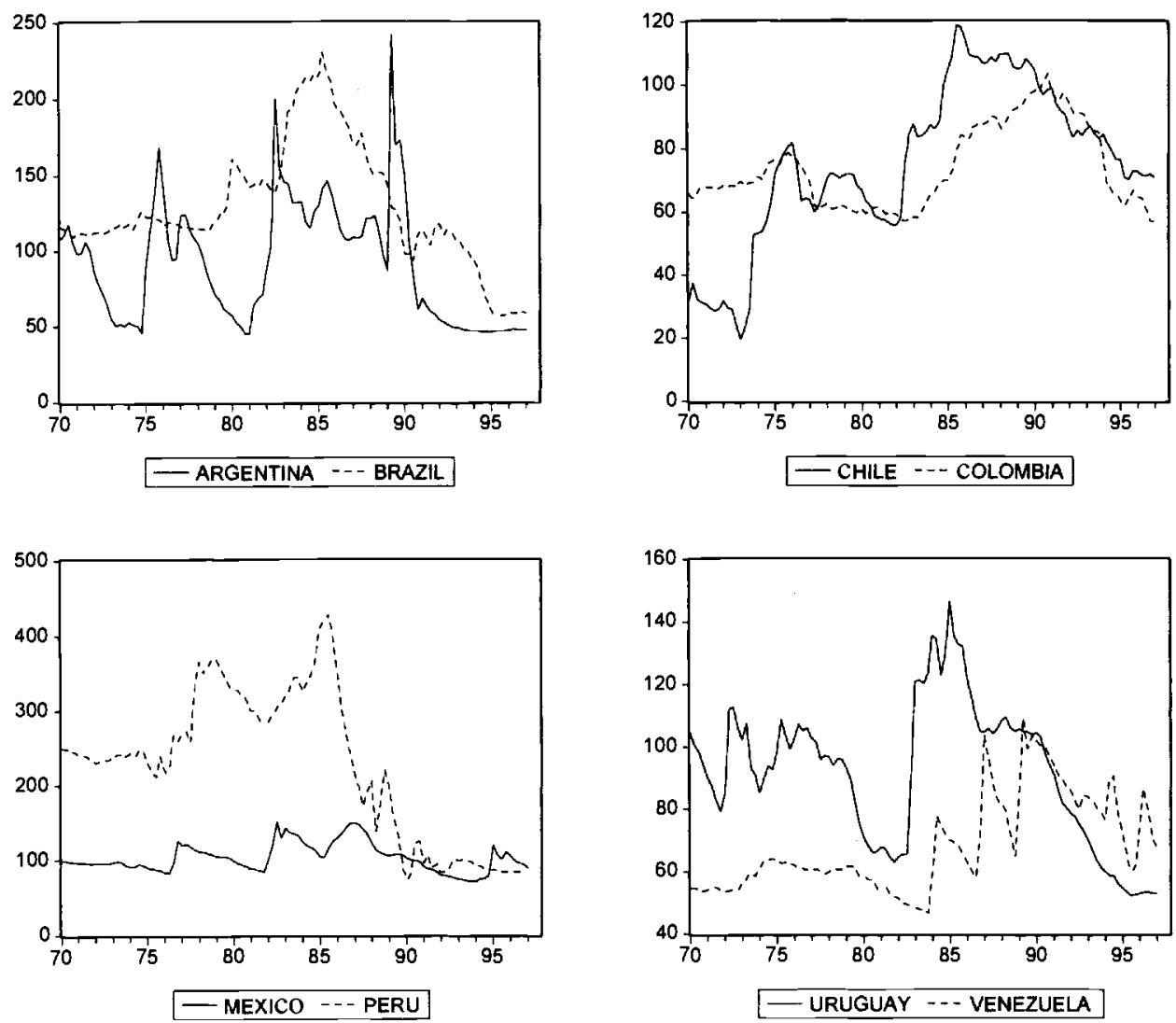

Fig. 1.6 Real exchange rate indexes for selected Latin American countries, 1970-97

nancial sector operators. As Calvo et al. (1993) have pointed out, however, real exchange rate appreciation generated by increased capital inflow is not a completely new phenomenon in Latin America. In the late 1970 s most countries in the region, and especially the Southern Cone nations, were flooded with foreign resources that led to large real appreciations. The fact that this previous episode ended in a debt crisis has added drama to the current concern about the possible negative effects of these capital flows.

Figure 1.6 presents the evolution of bilateral real exchange rate (RER) indexes for a selected group of Latin American countries for the period 1970-1997:1.5 An increase in the value of such an index represents a real depreciation and thus

5. These are bilateral indexes relative to the U.S. dollar and have a base of $1990=100$. In their construction the U.S. producer price index and each individual country consumer price index were used. 
an increase in the country's degree of international competitiveness. A number of characteristics of RER behavior in Latin America emerge from these figures. First, RERs have historically been very volatile in Latin America. Comparative analyses of RER behavior have indeed shown that, for long periods of time, RER variability has been greater in Latin America than in almost any other part of the world. Second, these figures show that in all eight countries the RER depreciated drastically after the 1982 debt crisis, only to experience a very large appreciation in the 1990s. These downward swings in RERs were largely caused, as I will argue later, by the surge of capital inflows in the 1990s. Third, these figures show that for most countries in the sample the appreciation trend has slowed in the past two or three quarters and, in some countries, it even seems to have ended.

Figure 1.7 shows the relationship between aggregate (net) capital inflows and the RER for a selected group of countries. ${ }^{6}$ As may be seen, in all the countries there is a negative relationship between capital inflows and the RER: increases in capital inflows have been associated with RER appreciation, while declines in inflows are associated with RER depreciation. I explore this relationship further in table 1.3, where I present correlation coefficients between a proxy for quarterly capital inflows and the RER index. As may be seen, in every one of the seven largest Latin American countries there is a negative relationship between capital inflows and the RER, and in some the coefficient of correlation is quite large (in absolute terms). This table also includes results from a series of causality tests. These show that in seven out of the eight cases it is not possible to reject the hypothesis that capital flows "cause" RERs; in three of the seven countries it is not possible to reject two-way causality; and in none of the seven cases analyzed is it found that RERs cause capital inflows. These results, then, provide some support for the view that the recent surge in capital flows has been (partly) responsible for generating the loss in real international competitiveness reported above.

The exact way in which capital inflows translate into RER appreciation depends on the nature of the nominal exchange rate system. Under a fixed exchange rate regime, the increased availability of foreign resources will result in international reserve accumulation at the central bank, monetary expansion, and increased inflation. This, in turn, will put pressure on the RER to appreciate. As is discussed in greater detail in section 1.1.5, many countries have tackled this problem by attempting to sterilize these flows. Under a flexible exchange rate regime, on the other hand, large capital inflows will generate a nominal-as well as real-exchange rate appreciation.

A number of analysts have argued that the appreciation of the RER following a surge in capital inflows is an equilibrium phenomenon - that is, one gen-

6. These are the countries for which the IMF provides quarterly data on aggregate capital inflows. In order to have a larger sample, in table 1.3 I have used quarterly changes in international reserves as a proxy for capital inflows. 
erated by fundamentals - and thus should not be cause for concern. This was, for example, the position taken by the Mexican authorities during 1991-94 when a number of independent observers argued that the real appreciation of the peso was not sustainable and was bound to generate a major currency crisis. ${ }^{7}$ The view that an increase in capital flows leads to an appreciation of the RER is correct from a simple theoretical perspective. Indeed, in order for the transfer of resources implied by higher capital inflows to become effective, a real appreciation is required. A limitation of this interpretation, however, is that it fails to recognize that the rate at which capital was flowing into Mexico in 1991-93-at levels exceeding 8 percent of GDP - was clearly not sustainable in the long run. This means that at some point the magnitude of the flow would have to be reduced, requiring a reversal in RER movement.

Although there are no mechanical rules for determining the volume of capital that can be maintained in the long run, there are some helpful guidelines that analysts can follow in order to detect departures from capital inflow sustainability. ${ }^{8}$ In general, there is an "equilibrium" level of a country's liabilities that foreigners are willing to hold in their portfolios. Naturally, this "equilibrium portfolio share" is not constant and depends, among other variables, on interest rate differentials, the perceived degrees of country and exchange risk, and the degree of openness of the economy. Moreover, when countries embark on (what is perceived to be) a successful reform program, the equilibrium level of the country's liabilities that is willingly held by international investors is likely to increase because they will be eager to take part in the country's "takeoff." In a recent paper Calvo and Mendoza (1996) argued that in a world with costly information it is even possible for very large volumes of capital to move across countries on the basis of rumors. They estimated that, in the case of Mexico, belief in a change in domestic returns by 0.5 percent could result in capital movements of approximately US $\$ 14$ billion.

The following simple framework provides a useful way for approaching the capital inflow sustainability issue: assume that in equilibrium international investors are willing to hold in their portfolios a ratio $k^{*}$ of the home country's (Mexico's, say) liabilities relative to its GDP. ${ }^{9}$ This ratio depends on a number of variables, including the country risk premium and interest rate differentials. If, for example, the perceived degree of country risk goes down, and the country is seen as more stable, $k^{*}$ will increase. This approach has two important implications. The first has to do with the long-run sustainable level of capital inflow and, thus, of the current account deficit. This depends on two factors: (1) international demand for the country's securities and (2) the real rate of growth of the economy. If, for example, foreign investors are willing to hold

7. For discussions of Mexico's RER appreciation in 1991-94 see, e.g., Dornbusch (1993), Dornbusch and Werner (1994), and Edwards (1993). On Mexico's official position regarding these developments see, e.g., Bank of Mexico (various years).

8. On the issue of current account sustainability see, among others, Reisen (1995).

9. Ideally this is a forward-looking measure of GDP. 

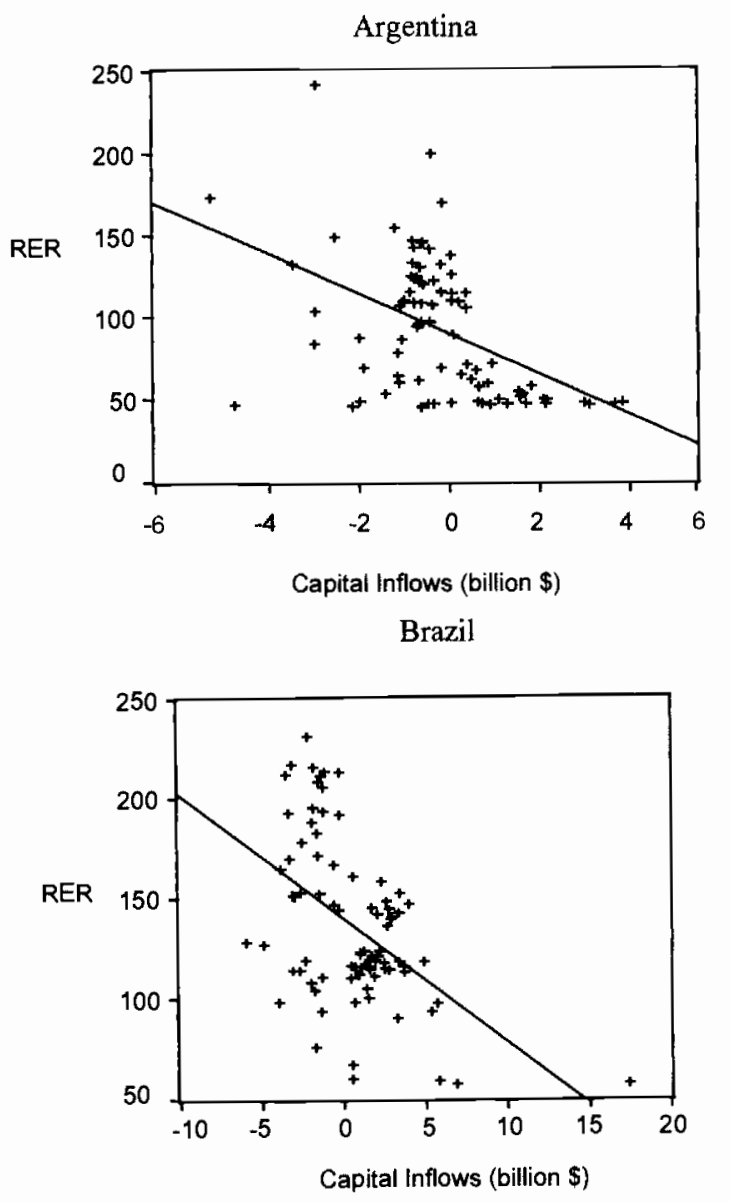

Chile

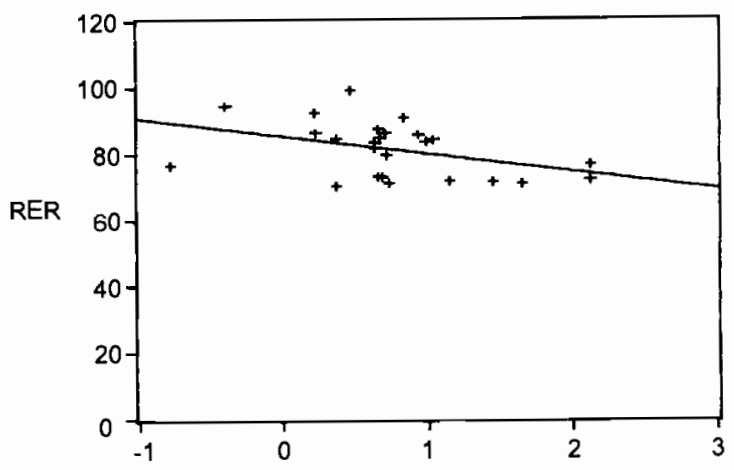

Capital Inflows (billion \$)

Fig. 1.7 Real exchange rate indexes versus capital inflows for selected Latin American countries, 1970-97 

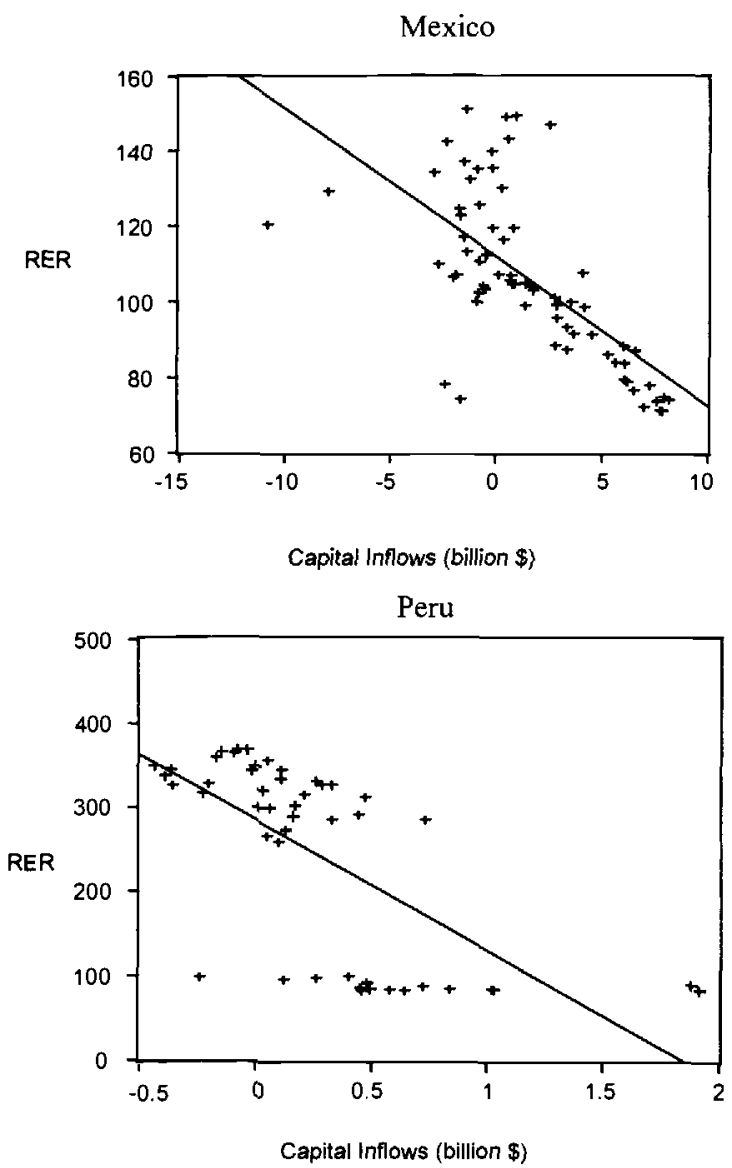

Fig. 1.7 (cont.)

national securities amounting to 50 percent of the country's GDP and the rate of growth is 4 percent per year, the long-run sustainable deficit is 2 percent of GDP. If, however, the demand for the country's securities is 75 percent of GDP, the sustainable current account deficit is 3 percent of GDP. More specifically, long-run sustainable capital inflow as a percentage of GDP is given by the following equation: ${ }^{10} C / y=g k^{*}$, where $C$ is the current account deficit, $y$ is GDP, $g$ is the real rate of growth of the country, and $k^{*}$ is the ratio to GDP of the country's liabilities that are willingly held by international investors. According to Bank of Mexico data, at their peak foreign holdings of Mexican securities reached approximately 50 percent of the country's GDP. Growth, however, averaged less than 4 percent during the first four years of the 1990s. These figures

10. This assumes that no international reserves are being accumulated. 
Table 1.3

Capital Inflows and Real Exchange Rates in Selected Latin American Countries: Some Basic Statistical Relations, Quarterly Data, 1980-97

\begin{tabular}{lccc}
\hline Country & $\begin{array}{c}\text { Correlation } \\
\text { Coefficient }\end{array}$ & $\begin{array}{c}\text { Do Capital Inflows } \\
\text { "Cause" Real } \\
\text { Exchange Rates? }\end{array}$ & $\begin{array}{c}\text { Do Real Exchange } \\
\text { Rates "Cause" } \\
\text { Capital Inflows? }\end{array}$ \\
\hline Argentina & -0.723 & Yes & No \\
Brazil & -0.727 & Yes & Yes \\
Chile & -0.382 & Yes & Yes \\
Colombia & -0.145 & No & No \\
Mexico & -0.656 & Yes & No \\
Peru & -0.478 & Yes & Yes \\
Venezuela & -0.146 & Yes & No \\
\hline
\end{tabular}

Note: Quarterly changes in international reserves were used as a proxy for capital inflows. Granger causality tests were performed. The results for Colombia and Venezuela are sensitive to the sample considered. If 1985-97 is used, the correlation coefficient is larger (in absolute terms), and in the case of Colombia it is not possible to reject the hypothesis that capital inflows "cause" real exchange rates.

indicate that Mexico's long-run sustainable current account deficit was in the neighborhood of 2 to 3 percent of GDP, significantly below the 7 to 8 percent levels actually attained during this period. On the other hand, in a country such as Chile, with a rate of growth of approximately 7 percent per year, the sustainable level of capital inflow is much larger. If, for instance, the steady state foreign demand for Chilean liabilities is 65 percent of the country's GDP, the sustainable inflow of capital is almost 6 percent of GDP.

The second implication of this framework is related to the dynamic effects of capital inflow on the current account and the RER. Transitional issues are particularly important when there are large shifts (positive or negative) in international portfolio demand for a small country's liabilities. If, for example, the country's degree of country risk drops, or if the country in question opens to the rest of the world, foreigners will increase their demand for the country's securities. In the short run-while the newly demanded securities are accumulated-capital inflow (and the current account deficit) will exceed in the short run, that is, it will overshoot, the level predicted by the preceding long-run analysis. Once portfolio equilibrium is regained, however, and investors hold in their portfolios the desired amount of the country's securities, capital inflow (and the capital account balance) will again revert to its long-run equilibrium level. In most instances this adjustment process will not be instantaneous. In some cases it will even take a few years. Historically, episodes of capital inflow surges have been characterized by increases in the demand for the small country's securities on the order of 20 to 30 percent of GDP, and by peak annual inflows on the order of 7 to 9 percent of GDP. Table 1.4 contains data on accumulated and maximum inflows during recent surges in Latin America.

One of the most important dynamic effects of the transition described above 
Table 1.4 Net Private Capital Inflows to Selected Latin American Countries, 1990s

\begin{tabular}{lccc}
\hline Country & $\begin{array}{c}\text { Inflow } \\
\text { Episode }^{\mathrm{a}}\end{array}$ & $\begin{array}{c}\text { Cumulative Inflow } \\
\text { at End of Episode }\end{array}$ & $\begin{array}{c}\text { Maximum Annual } \\
\text { Inflow }^{b}\end{array}$ \\
\hline Argentina & $1991-94$ & 9.7 & 3.8 \\
Brazil & $1992-95$ & 9.4 & 4.8 \\
Chile & $1989-95$ & 25.8 & 8.6 \\
Colombia & $1992-95$ & 16.2 & 6.2 \\
Mexico & $1989-94$ & 27.1 & 8.5 \\
Peru & $1990-95$ & 30.4 & 10.8 \\
Venezuela & $1992-93$ & 5.4 & 3.3 \\
\hline
\end{tabular}

Source: World Bank (1997).

aPeriod during which the country experienced a significant surge in net private capital inflow.

${ }^{\text {} N e t ~ l o n g-t e r m ~ i n t e r n a t i o n a l ~ p r i v a t e ~ c a p i t a l ~ a s ~ a ~ p e r c e n t a g e ~ o f ~ G D P . ~}$

is on the RER. As capital flows in, expenditure increases and the RER appreciates. Once capital stops flowing in, or even when the rate at which it flows slows down, the RER will be "overly" appreciated, and in order to maintain equilibrium, a massive adjustment may be required. The dynamics of capital inflow and current account adjustment will require, then, that the equilibrium RER first appreciate and then depreciate. And whereas during the surge in inflow the RER appreciates without impediment, when the availability of foreign capital declines nominal wage and price rigidity will make the required real depreciation difficult under a pegged exchange rate. ${ }^{11}$

Naturally, the situation is even more serious if, as a result of external or internal developments, the international portfolio demand for the country's securities declines - as was the case for Mexico after 20 December 1994 and for Argentina in the first half of 1995. Under these circumstances, the capital account balance suffers a very severe contraction-and the current account may even have to become positive-during the transitional period toward the new equilibrium. As is well known by now, whereas Mexico was unable to maintain the peg under the new circumstances, Argentina decided to stand firm and to engineer a major aggregate demand adjustment that generated a major hike in the rate of unemployment.

The effects of changing capital flows on the equilibrium RER, the current account, and reserve accumulation can be analyzed using simple numerical simulations. Edwards, Steiner, and Losada (1996) presented results based on a model of a small open economy with tradables and nontradables. In this framework, an increase in capital inflow allows residents of the country in question to increase expenditure on both types of goods. As a result of the surge in

11. This type of analysis has been made in relation to the sequencing of reform debate. See, e.g., Edwards (1984). 
capital inflow the current account deficit rises and the RER appreciates. The specific magnitudes of these effects depends on the price and expenditure elasticities of demand and supply of nontradables. This analysis suggests that, under plausible values for the relevant parameters, an increase in the international demand for a small country's securities equivalent to 20 percent of the country's GDP generates an inflow of capital that will peak at approximately 8 percent of GDP; note that these figures correspond closely to Latin America's historical experience reported in table 1.4. In turn, this inflow of capital will generate (under the assumed elasticities) an RER appreciation of almost 10 percent. Perhaps the most important aspect of this analysis is that it clearly shows that after capital inflow has peaked and begins to decline to its new level, the RER has to depreciate until it achieves its new equilibrium level. In a fixed exchange rate regime, this real depreciation can only be achieved by means of reducing domestic inflation to a rate below foreign inflation, or, in terms of the framework developed by Edwards et al. (1996), by actually reducing the price of nontradable goods.

The above discussion suggests that the relevant question regarding events in Mexico was not, as some analysts incorrectly thought during 1994, whether the inflows observed during 1991-93 were sustainable but how and when Mexico was going to adjust to a lower availability of foreign resources. Mexico's clinging to its rigid exchange rate system made a smooth landing increasingly unlikely as the events of 1994 unfolded.

\subsubsection{Capital Mobility and the Effectiveness of Monetary and Exchange Rate Policy}

Most Latin American countries have tried to minimize the macroeconomic - and in particular, the RER - consequences of capital inflow surges. Basically, three approaches have been used to deal with this phenomenon: (1) Some form of capital controls are imposed in order to slow the rate at which foreign funds come into the country. Brazil, Chile, and Colombia have relied on these types of controls. (2) Sterilized intervention is attempted in order to offset the monetary - and inflationary-consequences of capital inflow. Almost every country in the region has tried this approach. (3) Nominal exchange rate flexibility is increased. While, strictly speaking, the adoption of a more flexible exchange rate regime does not avoid the real appreciation, it accommodates the required real appreciation without a surge in domestic inflation. Chile is the only country that has used this mechanism to any serious extent-and for a long period of time. In addition to these three mechanisms there have been discussions in a number of countries about using fiscal adjustment to compensate for the monetary impact of capital inflows on the RER. In no country, however, has this discussion actually become implemented into policy. In this section I review some of the Latin American country experiences with these policy responses. 
Table 1.5

Restrictions on Capital Inflow to Chile

\begin{tabular}{|c|c|}
\hline Type of Capital Inflow & Restriction \\
\hline Direct foreign investment & $\begin{array}{l}\text { Minimum stay of one year. No restrictions on repatriation } \\
\text { of profits. }\end{array}$ \\
\hline $\begin{array}{l}\text { Portfolio inflows: issuing of } \\
\text { American Depository Receipts } \\
\text { (ADRs) }\end{array}$ & $\begin{array}{l}\text { The issuance of ADRs by Chilean companies is strictly } \\
\text { regulated. Only companies that meet a certain risk } \\
\text { classification requirement (BBB for nonfinancial } \\
\text { companies and BBB + for financial institutions) can } \\
\text { issue ADRs. There is also a minimum amount } \\
\text { requirement: until September } 1994 \text {, this was US } \$ 50 \\
\text { million; at that time it was lowered to } \$ 25 \text { million; and } \\
\text { in November } 1995 \text { it was further reduced to } \$ 10 \\
\text { million. }\end{array}$ \\
\hline Other portfolio inflows & $\begin{array}{l}\text { All other portfolio inflows--including secondary ADR } \\
\text { inflows, foreign loans, and bond issues-are subject } \\
\text { to a nonremunerated } 30 \% \text { reserve requirement. This } \\
\text { reserve requirement is independent of the length of } \\
\text { stay of the inflow. In the case of loan and bonds, the } \\
\text { recipient may choose to pay the financial cost of the } \\
\text { reserve requirement. }\end{array}$ \\
\hline Trade credit & $\begin{array}{l}\text { Credit lines used to finance trade operations are also } \\
\text { subject to the } 30 \% \text { deposit. }\end{array}$ \\
\hline
\end{tabular}

Source: Budnevich and Lefort (1997).

\section{Capital Controls in Chile and Colombia}

Chile and Colombia have relied on capital controls in an effort to avoid some of the destabilizing short-term effects-in particular, RER appreciation-of capital inflow surges. In their current form capital controls were introduced in 1991 in Chile and in 1993 in Colombia. ${ }^{12}$

In Chile these restrictions have taken two basic forms: minimum stay requirements for DFI flows and nonremunerated reserve requirements on other forms of capital inflow. Table 1.5 contains details on these regulations, as of the third quarter of 1997. In Colombia, on the other hand, capital controls have taken the form of a variable reserve requirement on foreign loans-except trade credit-obtained by the private sector. Initially, this reserve requirement was set at a rate of 47 percent and was only applicable to loans with a maturity shorter than eighteen months. During 1994, as the economy was flooded with capital inflows, the reserve requirements were tightened. In March they were extended to all loans with a maturity below three years; in August they were extended to loans of five years or less. Moreover, the rate of the reserve requirement became inversely proportional to the maturity of the loan: thirty-day loans were subject to a stiff 140 percent reserve requirement-which was vir-

12. It should be noted that both of these countries had a long tradition with capital controls before the 1990s. See, e.g., Edwards (1988b). 
tually prohibitive-while five-year loans had to meet a 42.8 percent deposit. See figure 1.8 for the actual reserve requirements for various loan maturities.

In both Chile and Colombia restrictions on capital movements act as an implicit tax on foreign financing. Recent studies by Cardenas and Barreras (1996) and Valdes-Prieto and Soto (1996) calculated the tax equivalence of these controls in order to analyze the effects of these restrictions on capital movements. In particular they estimated a number of capital inflow equations to investigate whether these mechanisms have succeeded in affecting the rate at which capital has flowed into countries. These authors found that aggregate capital inflows have not been sensitive to this tax equivalence factor and concluded that these capital restrictions have been ineffective in slowing capital movements. In both countries, however, capital controls have resulted in a change in the composition of capital inflows, with flows not affected by these implicit taxes growing faster than they would have otherwise (see Budnevich and Lefort 1997 and Larrain et al. 1997 for similar results). Valdes-Prieto and Soto (1996) persuasively argued that, in the case of Chile, the existence of capital controls has actually had an important negative effect on welfare for two reasons. First, to the extent that trade credit is subject to reserve requirements, these requirements are also an implicit barrier to free trade, and the economy is subject to the traditional welfare consequences of protectionism. Second, by introducing a wedge between domestic and foreign interest rates these controls result in a misallocation of intertemporal consumption and discourage investment.

In view of the questionable effectiveness of capital controls, policymakers in a number of countries have considered alternative mechanisms to smooth the volume of net capital inflows. Some analysts have argued that the relaxation of restrictions on capital outflows from developing countries provides an effective way of achieving this goal (Budnevich and Lefort 1997; World Bank 1997). According to this view, if domestic residents can freely move funds out of the country (for portfolio diversification or for other reasons), net inflows will be lower, and so will the pressure on money creation, inflation, and the RER. Laban and Larrain (1997), however, argued that a relaxation of restrictions on capital outflows may further complicate macroeconomic management. This will be the case if investors interpret the new policy as reducing the overall cost of investing in the country. This, in turn, will make investment more attractive than before and (perhaps paradoxically) will generate an increase in net capital inflows to the country.

\section{Sterilized Intervention: Is It Possible? How Costly Is It?}

Most countries in Latin America have tried to offset (at least partially) the monetary impact of the recent capital inflow surge. Several mechanisms have been used to this end, including increasing commercial banks' marginal reserve requirements, transferring public sector deposits to the central bank, which is equivalent to imposing a very high reserve requirement on this type of deposit, and undertaking sterilized intervention on behalf of the central 


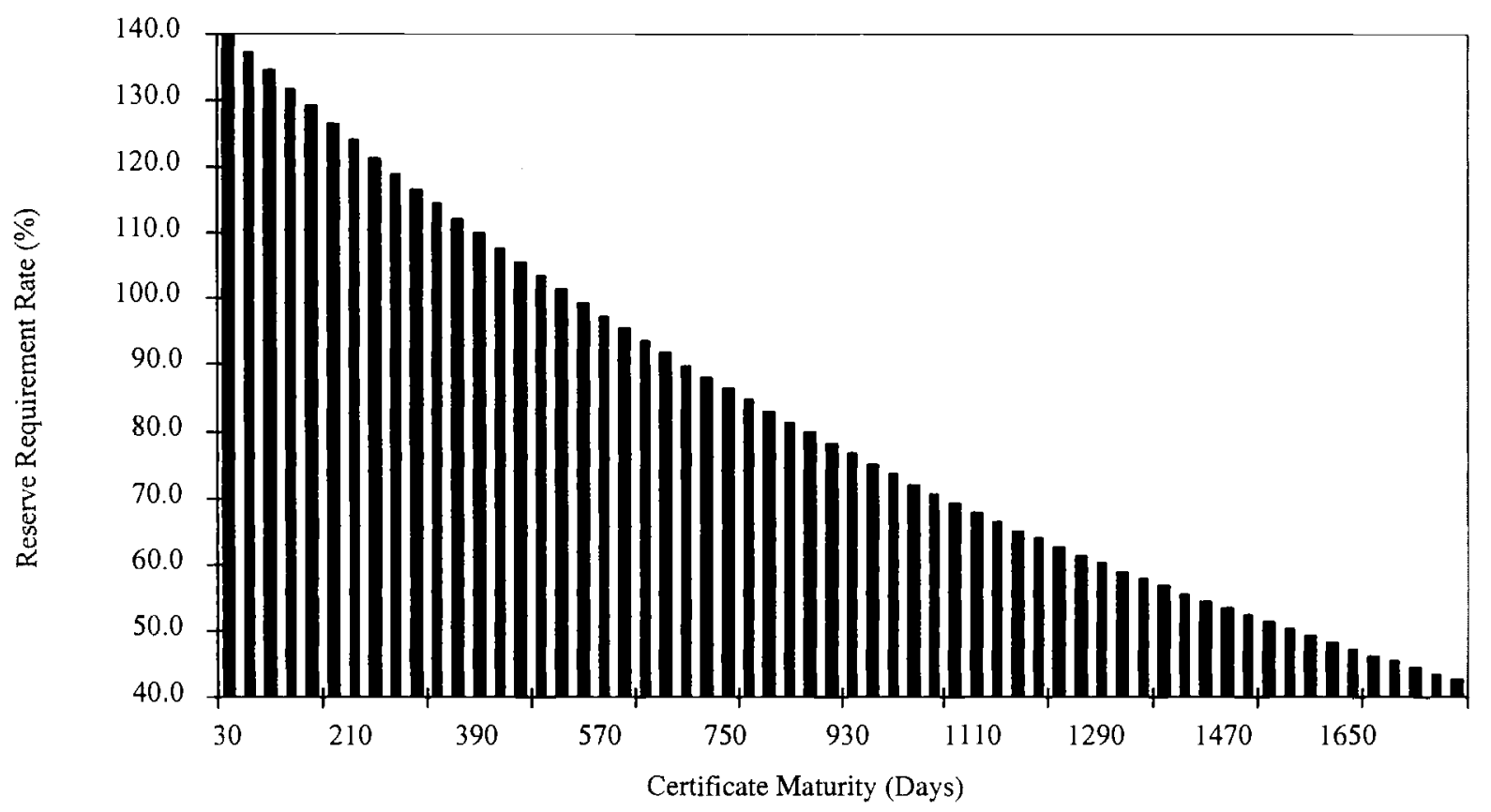

Fig. 1.8 Reserve requirement rate versus certificate maturity in Colombia, 1996 
bank. The last mechanism has been used in almost every country in the region and is usually carried out through the sale of central bank securities to the public at large. Figure 1.9 illustrates the extent of sterilization in Argentina, Colombia, and Mexico. As may be seen, in each of these countries changes in reserves have been associated, in the past few years, with changes in the opposite direction in domestic credit (during the same quarter).

A problem with sterilized intervention, however, is that it can be very costly for the central bank. This is because interest earnings on international reserves are rather low, while the central bank has to pay a relatively high interest rate to persuade the public to buy its own securities. Calvo (1991), for example, argued that this cost can become so high that it may end up threatening the sustainability of the entire reform effort. Moreover, as Frenkel (1995) pointed out, in an economy with capital mobility and predetermined nominal exchange rates it is not possible for the monetary authorities to control monetary aggregates in the medium to long run. This view has been confirmed by econometric estimates of the monetary "offset" coefficient for a number of countries (see, e.g., the studies in Steiner 1995).

Colombia's experience during the early 1990s illustrates very clearly what Calvo (1991) called "the perils of sterilization." In 1990 newly elected President Gaviria announced a trade liberalization program aimed at eliminating import licensing and greatly reducing import tariffs. At the same time a twentyyear-old exchange and capital control mechanism was eliminated. By March 1991, however, it was becoming clear that trade reform was not having the effects the economic team had anticipated. Perhaps the most surprising fact was that imports were not growing and that, as a result of it, the country was experiencing a growing trade surplus. This, in conjunction with larger inflows of capital, was putting pressure on the money supply, making macroeconomic management very difficult. As inflation increased, the RER began to lose ground, and both exporters and import-competing sectors began to lose competitiveness. The Banco de la Republica reacted to this situation by implementing a series of policies that in retrospect appear to have contradicted each other. First, an aggressive policy of sterilizing reserve accumulation was undertaken. This was done by issuing indexed short-term securities (the OMAs). In the first ten months of 1991 the stock of this instrument shot up from US $\$ 405$ million to $\$ 1.2$ billion, or 85 percent of the total monetary base. Naturally, this policy resulted in an increase in domestic (peso denominated) interest rates and a significant interest rate differential. This attracted further capital into the country, frustrating the sterilization policy itself. Second, the authorities decidedas they had in the past when facing coffee booms-to postpone the monetization of export proceeds. For this reason, in 1991 the monetary authority stopped buying foreign exchange in the spot market. Instead, it started issuing "exchange certificates" (certificados de cambio) in exchange for export foreign currency proceeds. These certificates could be transacted in the secondary market and initially had a three-month maturity, which was later extended to one 


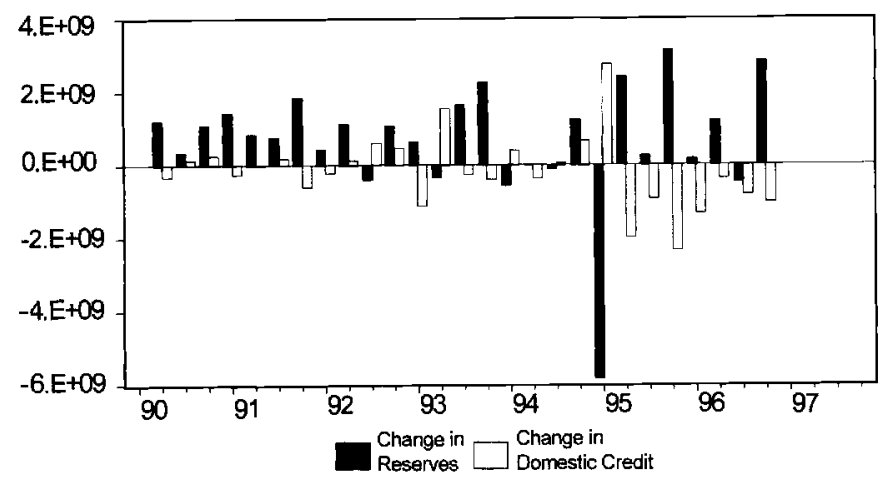

ARGENTINA
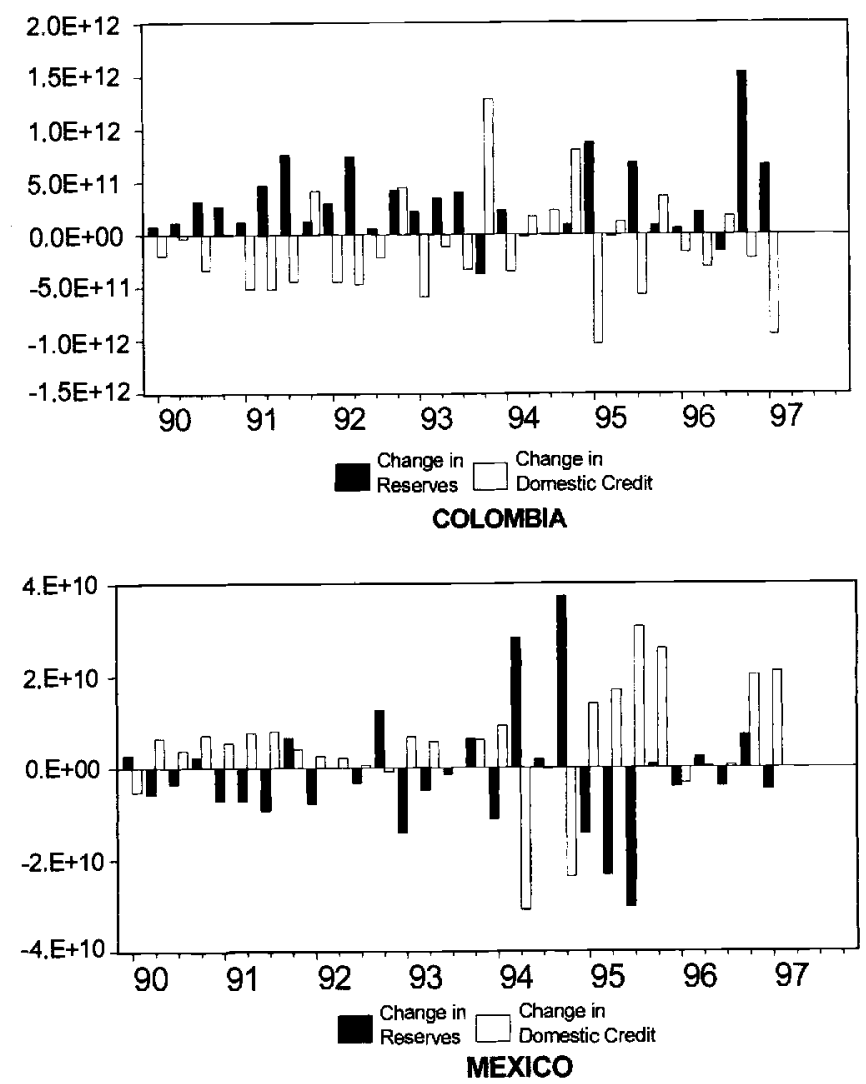

Fig. 1.9 Sterilized intervention in selected Latin American countries 
year. Moreover, the central bank established a maximum discount for the certificates in the secondary market of 12.5 percent. All of this, of course, amounted to an attempt at controlling too many variables - the spot and future exchange rates, the nominal interest rate, and the stock of money-at inconsistent levels. During the first ten months of 1991 Colombia was trapped in a vicious circle: a very rapid process of reserve accumulation generated high inflation and RER appreciation; but the policies put in place to combat these phenomena created incentives for capital inflows and further appreciation of the RER. These events generated two political problems for the Gaviria administration. First, exporters and import-competing sectors were becoming increasingly unhappy about the real appreciation of the peso; second, the lack of progress against inflation was a black spot in an otherwise quite positive picture.

\section{Nominal Exchange Rate Flexibility: Chile's Band Experience}

After a major and protracted macroeconomic crisis, in early 1986 Chile adopted a nominal exchange rate system based on a crawling band system. The band was originally quite narrow, allowing fluctuations of \pm 2 percent around a backward-looking crawling central parity. Through time, however, two innovations were introduced into the system. First, the band became wider, reaching \pm 12 percent in 1997; second, the central parity was defined relative to a three-currency basket. The latter measure was based on the idea that basket pegging would add some uncertainty to the system, discouraging (very) shortterm speculators. Throughout, however, the rate of crawl of the band has been backward looking and is determined as the previous month's rate of domestic inflation minus an estimate of international inflation. The adoption of this band was an integral part of an economic program aimed at achieving very fast rates of growth-mostly driven by export expansion-while reducing inflation.

Figure 1.10 presents the evolution of Chile's band and actual exchange rate since 1989. Four important features emerge from this figure. First, given the alterations introduced into the system the Chilean band has been, de facto, nonlinear relative to the U.S. dollar. Second, throughout much of the period the actual rate was at the bottom of the band. This has been the direct result of very large capital inflows, which created an abundance of foreign exchange. From all practical points of view, then, during this period the band acted as an effective floor for the nominal exchange rate. There is, in fact, little doubt that if it had not been for the band the nominal value of the peso would have appreciated significantly during the period. Third, the form of the band has given significant flexibility to the system, allowing the economy to accommodate external shocks, such as the (short lived) scare following the Mexican crisis of 1994. And fourth, the band has allowed the peso to remain very stable in nominal terms in the last eighteen to twenty-four months, taking away inflationary pressure from the system. Some evidence, however, suggests that the widening of the band added uncertainty to the economy and resulted in an increase in domestic interest rates. 


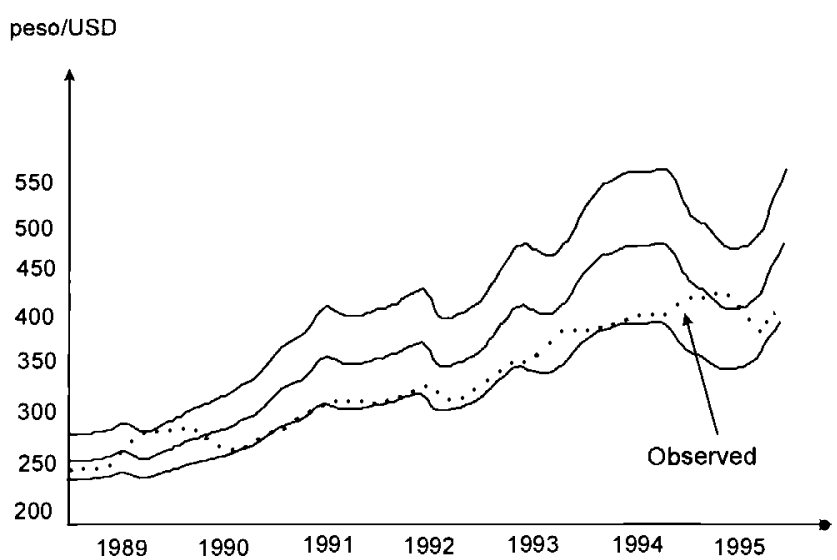

Fig. 1.10 Chile's band

Although the Chilean band it has not prevented RER appreciation, it has maintained it at a relatively controlled level. In fact, a new World Bank (1997) study indicated that the Chilean peso is still slightly undervalued. Moreover, the band has allowed the gradual reduction of inflation - in 1997 it will be approximately 5 percent. In fact, in spite of having an elaborate indexation system, Chile has been able to reduce the degree of inflationary inertia significantly. Given the relative success of the Chilean band system, it is surprising that more countries have not adopted this type of regime.

\subsubsection{The Role of the Domestic Banking Sector}

The resurgence of capital inflows to Latin America has raised some important questions: Will there be another reversal? Are institutional investors likely to behave in a herd fashion, as in the past? How vulnerable are the Latin American countries to a contagion effect coming out of East Asia or other emerging markets? The analysis presented in the preceding sections suggests that the conditions behind capital flows have changed. These appear to be less volatile than in the past, and investors are becoming more sophisticated and understand that there are significant differences among regions and countries. However, the issue of vulnerability remains. What makes the situation particularly difficult is that in many Latin American countries commercial banks-which (ultimately) intermediate capital inflows - continue to be financially weak, even in the aftermath of the Mexican crisis. Moreover, in most nations supervisory systems are inefficient and unable to monitor effectively the quality of the portfolio and the extent to which banks indeed abide by existing rules and regulations.

Latin America's own history justifies the current concern about banks' vulnerability. As previous episodes in the region have shown, when banks fail the effects of financial crises are greatly magnified. Past experiences in Chile and 
Mexico illustrate this point vividly. Banks were at the center of the Chilean crisis of 1982. After intermediating very large volumes of capital inflows during 1978-80, commercial banks became increasingly vulnerable to negative shocks stemming from the international economy. In mid-1981, as international interest rates increased rapidly, asset prices in Chile began to fall and the demand for deposits experienced a significant decline. Some firms had trouble paying their debts, and in November 1981 two major banks-Banco Español and Banco de Talca-ran into serious difficulties and had to be bailed out by the government. During late 1981 and early 1982 aggregate production collapsed, domestic interest rates continued to increase, and the number of bankruptcies increased greatly. In the first half of 1982 deposits in the Chilean banking system, especially deposits by foreigners, continued to decline steeply. During the first five months of 1982 alone, foreign deposits in commercial banks dropped by 75 percent. An interesting feature of the Chilean episode was that most commercial banks were owned by large conglomerates (the socalled grupos), which received major loans from the banks themselves. Many times these loans were made sidestepping financial criteria and were guaranteed by assets with highly inflated prices. In June 1982 the government decided to devalue the peso, in the hopes of alleviating speculative pressure on the economy. The devaluation, however, affected negatively the financial condition of many firms that had borrowed heavily in dollars. Depositors decided to fly from peso-denominated assets, commercial banks continued to accumulate bad loans, and the central bank had to inject large amounts of funds into the economy. In January 1983 the government concluded that the cost of this muddling-through strategy was too high and pulled the rug from under some of the major commercial banks. By mid-1983 a number of banks had gone bankrupt, and Chile's financial crisis was in full swing. At the end of the road the massive bank bailout that followed cost the country (in present value terms) in excess of 20 percent of GDP.

What makes this story fascinating is its parallel to the 1997-98 crises in Indonesia and Korea. All the key elements are there-a rigid exchange rate policy, marked overvaluation, a high current account deficit, reckless lending by conglomerate-controlled banks, poor bank supervision, and a major asset bubble. In fact, one cannot avoid thinking that, had watchers of East Asia studied the Chilean financial crisis of 1982, they would not have been so shocked by the turn of events in the countries once called Asian "tigers."

Similarly, it is possible to argue that both the magnitude and timing of the 1994 Mexican crisis were affected by the behavior of the banking system. Throughout 1994, as international interest rates increased and Mexico was hit by a series of political shocks, the Mexican authorities made great efforts to maintain domestic (peso denominated) interest rates at a relatively low level. A two-prong approach was followed: on the one hand, a cap was imposed on peso-denominated interest rates; on the other, the authorities issued increas- 
ingly large amounts of dollar-denominated securities-the so-called Tesobonos. The investment house J. P. Morgan summarized this state of affairs in its 22 July 1994 newsletter: "Half of the 28-day and 91-day Cetes [pesodenominated securities] were issued; the central bank would not accept the high yields required by the market to auction the full amount." And on 23 July the Economist pointed out that "the central bank has also had to issue plenty of tesobonos-dollar linked securities that are popular with investors that worry about currency risk." This strategy - which in retrospect has mystified so many analysts - partly addressed the Mexican authorities' concerns regarding the financial health of Mexican banks. This concern had begun in late 1992, when a large increase in past-due loans became evident. In 1990 nonperforming loans were estimated to be only 2 percent of total loans; that ratio increased to 4.7 percent in 1992, to 7.3 percent in 1993 , and to 8.3 percent at the end of the first quarter of 1994. With the fourth largest bank-Banca Cremiin serious trouble, the authorities tried to buy additional time as they worked out an emergency plan. By the end of the first semester the state development banks had developed a relief program based on some write-offs of commercial banks' past-due interest and government-issued loan guarantees. In the belief that the peso was sustainable and that they had superior information, Mexican banks engaged in aggressive derivative operations, accumulating sizable dollar-denominated off-balance-sheet liabilities (Garber 1996). On 19 December 1994, however, with the Bank of Mexico having virtually run out of reserves the Mexican authorities decided to widen the exchange rate band. It was too little, too late. In the months to come it became increasingly clear that a key element in the stabilization policy would be to contain - or at least minimize - the extent of the banking crisis.

\subsubsection{Concluding Remarks}

This paper has dealt with Latin America's experience with capital flows during the past decade and a half. It has covered a number of issues of increasing interest to academics and international observers, including the effect of capital inflows on domestic saving, the effect of capital mobility on the ability to engage in independent monetary policy, and the effectiveness of capital controls. The data analysis presented in section 1.1.2 shows that the Latin American countries have gone through wild cycles. In the mid- to late 1970s they benefited from the recycling of petrodollars and were flooded with private capital. After the eruption of the Mexican debt crisis in 1982, the international capital market dried up for every country in the region, and net private capital inflows became significantly negative. Things changed in 1991, when once again private capital began to pour into the region. Although this turn of events has largely been welcomed, it has also generated some concern among analysts and policymakers. In particular there are still questions about the sustainability 
of these flows, as well as about the extent to which the region will be affected by the still developing East Asian crisis. In early 1998 the consensus seems to be that this time around Latin America has strong fundamentals and is facing the crisis from a strong footing. This view is nicely summarized by the following quote from ING Barings: "Latin America is relatively insulated from the direct contagion effect of Asia. .. . The policy response of the Latin authorities to the recent turbulence in the emerging world has been impressive and the general resilience of Latin America to a more difficult global economic backdrop has much to do ... with an improving microeconomic base" $(1998,7)$.

\section{References}

Bank of Mexico. Various years. The Mexican economy. Mexico City: Banco de Mexico. Bruno, Michael. 1995. Currency crises and collapses: Comment. Brookings Papers on Economic Activity, no. 2:205-56.

Budnevich, Carlos, and Guillermo Lefort. 1997. Capital account regulations and macroeconomics policy: Two Latin American experiences. Working Paper no. 6. Santiago: Banco Central de Chile.

Calvo, Guillermo A. 1991. The perils of sterilization. IMF Staff Papers 38, no. 4 (December): $921-26$.

Calvo, Guillermo, Leonardo Leiderman, and Carmen Reinhart. 1993. Capital inflows and real exchange rate appreciation in Latin America: The role of external factors. IMF Staff Papers 40 (March): 108-51.

Calvo, Guillermo, and Enrique Mendoza. 1996. Rational herd behavior and the globalization of security markets. College Park: University of Maryland. Mimeograph.

Cardenas, Mauricio, and Felipe Barreras. 1996. On the effectiveness of capital controls in Colombia. Washington, D.C.: World Bank, International Finance Division. Processed.

Chuhan, Punam, Stijn Claessens, and Nlandu Mamingi. 1993. Equity and bond flows to Latin America and Asia: The role of global and country factors. Policy Research Working Paper no. 1160. Washington, D.C.: World Bank, International Economics Department.

Dornbusch, Rudiger. 1988. Our LDC debts. In The United States in the world economy, ed. Martin Feldstein. Chicago: University of Chicago Press.

1993. Mexico: How to recover stability and growth. Chapter 17 in Stabilization, debt, and reform. Englewood Cliffs, N.J.: Prentice-Hall.

Dornbusch, Rudiger, Ilan Goldfajn, and Rodrigo Valdes. 1995. Currency crises and collapses. Brookings Papers on Economic Activity, no. 2:219-93.

Dornbusch, Rudiger, and Alejandro Werner. 1994. Mexico: Stabilization, reform and no growth. Brookings Papers on Economic Activity, no. 1:253-315.

Edwards, Sebastian. 1984. The order of liberalization of the external sector in developing countries. Princeton Essays in International Finance, no. 156. Princeton, N.J.: Princeton University, International Finance Section.

- 1985. Money, the rate of devaluation, and interest rates in a semi-open economy: Colombia, 1968-82. Journal of Money, Credit and Banking 17 (1): 59-68.

.1988a. Exchange rate misalignment in developing countries. Baltimore: Johns Hopkins University Press. 
1988b. The United States and foreign competition in Latin America. In The United States in the world economy, ed. Martin Feldstein. Chicago: University of Chicago Press.

__ 1993. Latin America and the Caribbean: A decade after the debt crisis. Washington, D.C.: World Bank.

- ed. 1995a. Capital controls, exchange rates and monetary policy in the world economy. Cambridge: Cambridge University Press.

- 1995b. Crisis and reform in Latin America: From despair to hope. New York: Oxford University Press.

- 1996. Why are Latin America's savings rates so low? An international comparative analysis. Journal of Development Economics 51 (1): 5-44.

Edwards, S., and M. Khan. 1985. Interest determination in developing countries: A conceptual framework. IMF Staff Papers 32, no. 3 (September): 377-403.

Edwards, Sebastian, Roberto Steiner, and Fernando Losada. 1996. Capital inflows, the real exchange rate and the Mexican crisis of 1994. In Stabilization and reforms in Latin America: Where do we stand? ed. Hermann Sautter and Rolf Schinke. Frankfurt: Vervuert Verlag; Madrid: Iberoamericana.

Feldstein, Martin, and Charles Horioka. 1980. Domestic saving and international capital flows. Economic Journal 90 (June): 314-29.

Frankel, J. 1989. Quantifying international capital mobility in the 1980s. NBER Working Paper no. 2856. Cambridge, Mass.: National Bureau of Economic Research, February.

Frenkel, Jacob. 1995. The order of liberalization. In Economic policy in a world of change, ed. K. Brunner and A. H. Meltzer. Amsterdam: North-Holland.

Garber, Peter. 1996. Managing risk to financial markets from volatile capital flows: The role of prudential regulation. International Journal of Finance and Economics 1 (July): 150-69.

Haque, Nadeem, and Peter Montiel. 1991. Capital mobility in developing countries: Some empirical tests. World Development 19 (October): 91-98.

Harberger, Arnold. 1978. Perspectives on capital and technology in less developed countries. In Contemporary economic analysis, ed. M. Artis and A. Nobay, 151-69. London: Croom Helm.

1980. Vignettes on the world capital markets. American Economic Review 70, no. 2 (May): 331-37.

ING Barings. 1998. Global investment strategy. New York: ING Barings, first quarter.

Laban, Raul, and Felipe Larrain. 1997. Can a liberalization of capital outflows increase net capital inflows? Development Discussion Paper no. 584. Cambridge, Mass.: Harvard University, Harvard Institute for International Development.

Larrain, Felipe, Raul Laban, and Romulo Chumacero. 1997. What determines capital inflows? An empirical analysis for Chile. Development Discussion Paper no. 590. Cambridge, Mass.: Harvard University, Harvard Institute for International Development.

Montiel, Peter. 1994. Capital mobility in developing countries: Some measurement issues and empirical estimates. World Bank Economic Review 8, no. 3 (September): $311-50$.

Morgan Guaranty and Trust Company. 1987. World financial markets. New York: Morgan Guaranty International Economics Department

Ocampo, Jose Antonio. 1989. Colombia and the Latin American debt crisis. In Debt, adjustment and recovery, ed. Sebastian Edwards and Felipe Larrain. Oxford: Blackwell.

Reisen, Helmut. 1995. Liberalizing foreign investments by pension funds: Positive and normative aspects. World Development 25 , no. 7 (July): 1173-82.

Reisen, H., and H. Yeches. 1991. Time-varying estimates on the openness of the capital 
account in Korea and Taiwan. OECD Development Centre Technical Paper no. 42. Paris: Organization for Economic Cooperation and Development, August.

Steiner, Roberto. 1995. Flujos de capitales en America Latina. Bogota: Tercer MunoFedesarrollo.

Valdes-Prieto, Salvador, and Marcelo Soto. 1996. New selective capital controls in Chile: Are they effective? Santiago: Catholic University of Chile, Economics Department. Processed.

World Bank. 1997. Private capital flows to developing countries: The road to financial integration. New York: Oxford University Press.

\section{Francisco Gil Diaz.}

I would like to speak based on Mexico's recent experience, by which I mean especially the post-crisis period, and to compare it with the precrisis behavior of short-term capital flows. Some hypothesis is needed as to why they were so volatile and so large before the crisis, and why they have apparently shown such stable behavior after the crisis.

Mexico's recent and varied experience with international capital flows may throw some light on the interaction between such flows and different exchange rate regimes. To do so, it will be profitable to go from the present back to the past, by inspecting the behavior of a flow category that has worried policymakers because of its short-term nature and high volatility, especially given the speed and liquidity that characterize today's financial markets. The concern about short-term foreign capital flows is well founded, because of the sometimes ravaging effects of their injection and withdrawal on the financial stability and short-term output behavior of many economies.

To start the analysis with the most recent figures, consider the stock amounts invested by foreign residents in Mexico's money market between December 1995 and 8 October 1997. These quantities correspond to foreign resident purchases of government securities or commercial banks' money market instruments. The period chosen is significant because prior to December 1995 the figures are substantially contaminated by the liquidation by Mexico's federal government of the outstanding amounts of Tesobonos, the now infamous dollar-linked peso securities first issued at the end of 1991 .

At the end of December 1995, the stock amount, not the flow, of these investments in Mexican government securities and private financial money market instruments was $\$ 3.8$ billion. In December 1996 , the amount was $\$ 3.9$ billion, essentially the same number. And by the end of the first week of October of this year, it was $\$ 4.3$ billion. So over the course of almost two years the increase has been a mere $\$ 500$ million, or nothing. The figure has stayed basically the same.

The ups and downs of this concept over the twenty-three-month span, as well as its change from the beginning to the end of this period, were minimal. 
This behavior is remarkable given the large influx of other categories of foreign resident capital into Mexico over the same period: during the past two years, the country has been the second largest recipient of foreign direct investment in the world, second only to China. It has also received large amounts channeled toward equity purchases, as well as a resumption of foreign bank loans and the floating of private liabilities in international money markets. In 1997, these flows will have contributed to financing a current account deficit of about $\$ 7$ billion, plus an increase in international reserves in excess of $\$ 10$ billion.

That is a flow of $\$ 17+$ billion for this year, and yet the increase in shortterm money entering Mexico was insignificant. Not only has the amount of foreign money channeled to Mexican monetary instruments remained stationary over this period, but its term to maturity is considerably longer than the fortyeight-hour investments that flowed in large quantities prior to the 1995 crisis. The instruments now being purchased by foreign residents tend to have a maturity of at least three months, with six months to one year being the favorites.

The shift in the exchange rate regime between the precrisis and postcrisis periods may explain the radical change in the nature of foreign capital flows into Mexico. The current lack of volatile capital flows may, in turn, hold the key to understanding the remarkable stability of the exchange rate over this recent period, as well as the perilous situation into which the Mexican economy fell before 1995. The fixed, or quasi-fixed, exchange rate that prevailed at the time, without the automatic self-adjusting processes of a currency board, generated diverse pathological market behaviors.

First, when the exchange rate veered toward the floor of its initially narrow peso-dollar band, it attracted large volumes of short-term capital inflows, because as long as the exchange rate stuck to its floor, investors would continue to obtain the high yields that had attracted them in the first place. But investors knew that the higher yields were possibly transitory under such circumstances, because the availability of hard currency, despite the implicit promise of convertibility, had as a limit some percentage of the international reserves of the central bank. The interest rate required to bring capital in, given those uncertainties, had therefore to contain some premium, and the term for which money market investors were willing to commit their capital had to be extremely short, allowing them to keep one foot inside and the other outside, so to speak.

Second, the other extreme possibility was for the exchange rate to be at its peso-dollar ceiling, sustainable as long as the central bank had sufficient international reserves. But when the exchange rate drifted toward the top of the pesodollar band, the incentive for investors was to try to be the first out of the local currency, in a situation so desperate that virtually no interest rate could be high enough to encourage them to stay.

An exchange rate system with bands, therefore, appears likely to generate two polar possibilities. One is to attract vast foreign inflows invested in extremely short-term instruments; the other, to have investors trying to fly away as quickly as possible. 
But this is old stuff, of course. That exchange rates tend to veer off to their allowable extremes, and that, once there, the system has all the flaws and dangers of a fixed exchange rate, was pointed out several decades ago by Harry Johnson. Otherwise, if the exchange rate does not stick to either of its extremes, the system behaves as a floating exchange rate. So why contaminate it with bands? Unfortunately, it seems necessary to continue rebottling old wines for the consumption of some economists, as well as for policymakers.

A careful empirical study performed by Trigueros provides some interesting statistical results along this line of reasoning. He concluded that foreign direct investment, portfolio investment, and foreign currency deposits issued by commercial banks, as well as the direct credit they obtained, exhibited remarkable stability in Mexico after the onset of the crisis. The opposite is true of foreign exchange inflows to the Mexican money market prior to the crisis, when in the period from 1990 to September $1994 \$ 40$ billion in short-term capital poured into Mexico.

The immediate postcrisis period, that is to say 1995, is atypical, because during that year the Mexican government decided to stop issuing Tesobonos and to liquidate those outstanding. The behavior of short-term capital from December 1995 up to the present has already been detailed above.

Another question related to the interplay between economic crisis and international capital flows is whether the latter are the outcome of capricious movements of fickle investors whose behavior has to be molded through multiple equilibria, which have multiple trajectories and multiple landing strips, or whether the flows respond rather to fundamental causes within the economies that become subject to attack.

Historical evidence recently presented by Michael Bordo and Anna Schwartz, and the contemporaneous experiences of some Asian countries, together with the roots of the Mexican crisis, point to a rational, if sometimes belated, response on the part of investors. The Mexican crisis and the recent problems in Thailand, Malaysia, and Indonesia bear some striking similarities.

Credit growth in the private sector was astronomical in Mexico prior to the crisis, 25 percent per year in real terms for six years. The quality of the expenditures financed was poor or nonexistent in large part, even before the situation was aggravated by the blows inflicted on borrowers, as interest rates rose and the exchange rate depreciated after December 1994. The capitalization of some banks was thin or completely transparent. The quality of the human capital of banks had eroded considerably because of the years spent under government ownership. The liberalization of the banking system, which, among other changes, freed banks from the obligation to finance some sectors, liberated interest rates and eliminated reserve requirements. All these changes combined with suddenly copious resources to induce an increase in aggregate demand that would widen quickly and excessively the deficit in the current account of the balance of payments. 
We know now that the Asian countries that collapsed also experienced vast credit expansions of dubious quality. The similarities between the Mexican and Thai crises, and others, include as well an astronomical increase in real estate prices. Real estate prices in Mexico City rose 17.6-fold between December 1987 and December 1994, while the consumer price index over the same time span rose 3.6-fold; and an excessive expansion of mortgage credit into housing and office building booms artificially supported the asset price bubble. More fundamentally, because of their exchange rate systems, both countries attracted fatal amounts of short-term money. The similarities end there, however, because the export growth of some of the Asian countries had petered out by the time of their crises, while Mexico's nonoil exports were growing in 1994 at a pace of 20 percent, over an already very high base.

Contrary to some widely held perceptions, information concerning the behavior of the Mexican economy was available to anyone who wanted to see it. Data on the balance of payments, the nature, size, and volatility of capital flows, the size and speed of the expansion of credit, and the growth of the nonperforming portfolio of the banks were there for anyone to see, with a timeliness and quality equaled even then by few countries.

As we realize the nature of Mexico's and of other recent crises, a fundamental question arises: What should economists watch?

Another issue is the appropriate exchange rate regime. Some may opt for what I believe are the increasingly futile bands, others for flexible exchange rates. Experience suggests that the answer may be found at either of two extremes: either no autonomous issuing of currency at all-with the currency board as an approximation of this solution-or a flexible exchange rate. However, it is important to set out the conditions for a well-functioning flexible exchange rate. It is not sufficient to simply let it loose. Among other ingredients, coverage mechanisms are essential, but especially in immediate postcrisis periods. Institutions that allow for cover may not be sufficient, however. Investors have to be assured of the delivery of hard currency at the end of the leg of a transaction. The importance of this ingredient was evident at the outset of the Mexican crisis. Despite the existence of a deep market in forward contracts, the foreign exchange market did not contribute to the stabilization of the peso and of local interest rates until delivery became guaranteed with the appearance of futures transactions on the Chicago Merchantile Exchange.

Having expanded on the pros and cons of alternative exchange rate regimes and other implications for the attraction of particular capital flows, I should pay tribute to the obvious. Recent currency stability in Mexico may have been aided by the different elements detailed in this paper, but it would not have been possible without the deep adjustment made in the government budget, without wage revisions that have not outstripped gains in productivity, or without political stability.

I would like to end by quoting a remark James Meigs made at this week's 
CATO conference: "The only way to avoid an accident when your ship is heading windward onto a reef in the middle of a storm, is not to get into such a situation in the first place."

Let me add something to what I said before, and that is about the Fed tightening in $1994 .{ }^{1}$ I most certainly agree that the Fed tightening in the early $1980 \mathrm{~s}$ is an important part of the explanation of economic behavior at the time. Rates went up dramatically. It had a big impact on the U.S. economy. It had a big impact on export prices from Latin America. But did the 1994 change really matter that much to Mexico, or did the political shocks of that year trigger the crisis, together with the fact that Mexico's current account was getting so far out of line? How important are those, in retrospect, relatively small movements of U.S. interest rates in 1994 as a driver of what happened to the peso-dollar exchange rate?

Edwards's comments on the movements in the yield of the thirty-year bond are on target. Such movements are often premonitory of tightening by the Fed, as is the expectation of tightening by the Fed. Now that we are floating, these effects take about fifteen minutes to take hold-they are like an electric charge to the market. The moment we have the price of a thirty-year Treasury bond falling, right away we have our exchange rate depreciating and our interest rates rising, and vice versa when the price rises. I don't know if anyone has found a correlation between these hourly movements, but it doesn't really matter. We feel it every day by the hour.

But in 1994, Edwards is quite right, these effects took somewhat longer. Maybe it was because, as Fraga was saying, there was a lot of confidence in the economic team. Whatever the reason, it took somewhat longer, and I think it was the political events that had the first impact, although sooner or later rising interest rates also had an effect on the flows out of Mexico.

Peter Garber asked about the capitalization, the price paid for the banks and how that impinged on their performance. There were three kinds of banks, or three groups or tiers of purchasers of banks. One tier immediately started figuring out how to conduct fraudulent operations with their banks. It isn't a question of bad loans; it's a question of black holes in their accounts, money that hasn't been found. You can go up to several billion dollars when you're looking at those operations. So it wasn't an isolated case of maybe a loan or a sour operation. Some of these small and medium-sized banks, which were in the hands of people who are now being prosecuted or who are abroad facing extradition by the Mexican government, lost funds that were simply channeled to their owners' private uses.

The next tier raised the money needed to bid for the banks by convincing many people that they would enjoy large capital gains and telling them that as soon as they had control of the bank, investors would obtain loans to pay for

1. The remainder of this comment addresses points raised during the discussion. 
the shares they were committing to buy. So in those cases it wasn't a problem of having paid too much for the banks, but often of having paid too little or nothing, because once you consolidated the assets with the liabilities there was no capital left in some cases.

Third is the tier where the two big banks are situated, as well as some others, some very small ones actually. In this tier you find that real capital was put in, and there were no fraudulent schemes; but even in these cases there was some poor lending, although most of this bad lending took place before the banks were privatized.

The reason is that before the liberalization of the financial system came a reduction in government debt. Internal government debt went down from 20 percent of GDP to 5 percent of GDP over a couple of years. Five percent is still a large amount, as Fraga says, because 5 percent of GDP is a lot of money. Nevertheless, the internal debt of the government fell by 75 percent as the proceeds of the privatization of all kinds of firms, as well as some government surpluses, went to pay off that debt. That created a huge amount of leeway for banks to lend, and that activity was already happening when the banks were still in the government sector. The successful renegotiation of the government's external debt was concluded before the banks were privatized, and this fact alone allowed the banks to obtain substantial amounts of foreign resources. So credit started to increase very quickly at that time, and bad loans were being generated even then.

The other question that Garber raises goes beyond the numbers I presented, because I state that the amounts invested by foreigners in money market instruments have not changed much, but he says that the system can be shorted in several other ways, and that maybe such movements are not reflected in those statistics. And he is quite right. I don't think anybody knows. The amounts that investors can move around by using derivatives are much larger than the amounts I mentioned, although presumably there have not been very wide swings, given the stability of the exchange rate over recent years. I did not want to downplay this factor but rather to emphasize the useful information that is available. Moreover, regardless of information not available, I think you should worry if you see a bank whose portfolio is increasing by leaps and bounds, and more so when you see a whole system behaving that way. That's a rule of thumb for anybody analyzing a banking system, or an individual bank. And that's what was happening. We provided that information every month, with a threemonth lag, which is a very short lag for information about a whole banking system.

We had, of course, current account data. And while, just as Paul Krugman suggested, I wouldn't worry too much about the current account per se, I would perhaps about the relationship between the current account deficit as a proportion to GDP and the growth of GDP - the sustainability issue raised by Edwards-because it is not so much the current account, but how much debt you are incurring. If your current account is small enough in relation to your 
growth, then, if that money has been well invested, you are not necessarily getting into a more precarious situation. But in the case of Mexico, the ratio of the current account to GDP was growing much faster than GDP. And also the structure of its financing, because of many factors that combined to produce that structure, was so short term and so volatile that eventually we got into problems.

Now I would like to say something about international reserves, because even though Agustín Carstens and I wrote and published a paper about them, I think we haven't got the point across. The number that was provided for the amount of international reserves of the central bank, which was already quite low, was released in November 1994 at the bankers' convention, and it was widely published and widely known. So we were not hiding anything. Maybe nobody wants to acknowledge it today, but we certainly did release that number, and it was accurate. Now we publish it every week and nobody follows it any more.

Andrew Crockett raised the question of optimal exchange rate strategy, and somebody else mentioned, I think it was Fraga, that the Argentine mechanism worked not because it was automatic, but because there was support. I certainly agree with that. No system can withstand a massive and persistent currency attack, a speculative attack, or can resist it without any effects on the system. I suppose that a currency board and a flexible exchange rate are ways of making things more transparent and more immediate, but there are certainly no vaccines against crisis if an attack is strong enough. What would be the optimal strategy for South America? I have very little knowledge.

Finally, related to current account information, I would like to end by commenting that some years ago Milton Friedman said that current account figures shouldn't be published. They should be abolished. So he concurs completely with Krugman's point of view.

\section{Arminio Fraga}

In my remarks I will take the viewpoint of a practitioner, which is what I have been for many years. First, a bit of background. I fully agree with Sebastian Edwards's view that capital flows to Latin America have been hot and cold, or up and down as he says. That has certainly been the case for a long time, as a wonderful book by Carlos Marichal (1989) clearly demonstrates.

In most crises reviewed by Marichal swings in the supply of funds played a very important if not key role. Work by Calvo, Leiderman, and Reinhart (1993) on this subject highlights and supports this view. Their research presents evidence that factors external to a country's domestic fundamentals frequently drive the flow of funds to and from the country. For instance, when monetary 
policy is loose in the main financial centers, the developing countries tend to have easy access to capital. Conversely, countries typically face problems following a Fed tightening, a financial crisis, a war, and so forth. Recent examples include the Fed tightening engineered by Volcker in the early 1980s followed by the debt crisis and the more recent Mexican crisis, which came on the heels of the relentless tightening of 1994 .

Some vulnerability was present in the first place in all of these cases. This vulnerability is often a product of the excesses of the boom years, again in classic fashion, à la Kindleberger (1978). Some of the signs that trouble may be brewing include drastic real exchange rate appreciations, as well as complacency in the financial sector associated with loan growth that outstrips real GDP growth several times over. These and other signs are commonly associated with periods in which capital comes too easily.

Naturally each crisis has a slightly different flavor. For example, in the 1980s, in Latin America, one could argue that the crisis was driven by foreign borrowing, which was financing budget deficits. A lesson was learned: that was not a good idea. Then perhaps we could say in the 1990s that capital flows were financing consumption. Again, not a very good idea, because it doesn't generate any capacity to repay. And one could argue in the case of Asia more recently that overinvesting also ends up exposing the borrower to the risk of a crisis.

One factor, however, seems to be there every single time. This is my own undocumented experience, or somewhat documented; I have studied the crises of the 1980s and the 1930s. That factor is short-term debt. The danger signal for us investors that seems to be clear-maybe clearest of all, next to banking abuses-is the excessive accumulation of short-term debt. It usually comes toward the end of a credit cycle, again in standard Kindleberger fashion.

From a conceptual standpoint it is somewhat puzzling why the maturity profile of a country's debt is important. In a world where derivatives are available maybe it shouldn't matter that much. But it seems that it does matter.

One explanation that is consistent with a world where investors can create their own interest rate and currency risk profiles (by engaging in transactions such as swaps, forwards, futures, or options) is the fact that the production function for derivatives requires the use of balance sheets of banks and other institutions. And when the stock of short-term debt outstanding is large, financial intermediaries have no difficulty producing derivative instruments to sell short a given currency: they simply borrow the short-term instruments and sell them in the marketplace.

Take the Mexican case as an example. It was very hard to sell the peso short during the period that preceded the crisis because the Mexican authorities strongly discouraged Mexican banks from offering currency forwards. However, with the large stock of outstanding peso-denominated treasury bills (known by their Spanish acronym CETES) shorting the peso was not impossible: one could borrow Cetes and sell them short, thus effectively shorting the 
peso. To conclude, excessive short-term debt is risky not only because of the standard rollover risk it entails but also because it allows investors to take short positions more easily even in the presence of other restrictions. If a large stock of short-term debt had not been there, perhaps Mexico would not have been so vulnerable.

This brings me to an interesting question, and an important one. Somebody is borrowing short term, and one can come up with a lot of reasons why. Governments, for example, tend to have short horizons. They typically don't care much beyond their own administrations. But what about investors? Why do they finance these financial parties? Why do they stick around for so long? I guess one could invoke some sort of disaster myopia, in the style of what used to be the explanation for the debt crisis of the 1980s. Additionally, one can observe in the markets what could be characterized as trend-following behavior, whereby investors ride their winners. Financial flows tend to follow good performance. Derivatives also tend to generate this pattern, as we learned from the research on the portfolio insurance practices of some years back.

Another element that deserves to be highlighted in the context of this discussion is the role of governments and their policies in the process. Governments, for whatever reason, usually for political reasons, often try to defend situations that are clearly unsustainable. And when governments have a history of success and are good at telling their story, investors tend to hear it, at least for some time. This further delays the needed adjustment. The recent crisis in Thailand is a perfect example. Were it not for the spectacular successes of Thailand in the previous decade it would not have been possible to build the imbalances that eventually caused the Thai collapse in 1997.

The market patterns observed in the Mexican and Thai crises are fairly standard. The story typically begins with good fundamentals initiating a positive trend. There then follows a phase of complacency in which the trend continues despite the surfacing of economic and financial excesses. Moreover, in both these countries policies in place at a microeconomic level created incentives for a rapid build-up of foreign and domestic indebtedness. Finally, reality catches up with the markets and the trend is broken, frequently in violent fashion. Then we start over again ...

I would now like to discuss some cases in Latin America. I'll start with Mexico-very briefly because I generally agree with the presentation by Francisco Gil Diaz. For Mexico, the break came with the devaluation of 1994-95. Before the crisis Mexico displayed a growing current account deficit and a declining rate of saving. This meant that inflows of external capital were in effect financing consumption. These inflows, in turn, were increasingly characterized by short maturities, a clear vulnerability as discussed above. As if that was not enough, Mexico was then hit by two exogenous shocks: the Fed tightening and the political events and assassinations of 1994. These were some of the key causal ingredients of the crisis.

An interesting question to me is, Why did it take so long? That brings us to 
the first trend, the one that went all the way to the cliff. There were a lot of reasons for the longevity of this trend, starting with the high quality of government officials in Mexico, who really did a great job up until the very end. Until 1993 the Mexican story made a lot of sense, despite the growing current account deficit. Additionally, as mentioned above, it was difficult to sell the peso short. The government of Mexico was always informally on top of the situation, trying not to allow a market for peso derivatives to develop. That may have been a case where partial liberalization worked against Mexico, because while it was easy to bring short-term capital into Mexico, it was hard to hedge it. Perhaps the absence of foreign banks in Mexico also led to what Gil Diaz described as a poorly managed banking system, after the privatization, when the banks were basically bought by brokers.

Mexico's response to the crisis and the support package it received are well known. The recovery came swiftly and brought with it a renewed sense of stability, as discussed by Gil Diaz. This stability is in large part due to the prudent management of fiscal and monetary policies, which in turn lead to the absence of short-term debt. One consequence of this successful adjustment has been a continuous appreciation of the peso in real terms. One potential risk to be monitored in this context is that if the currency appreciates all the way back to where it was before the crisis, we may see the same movie again. This is a very difficult policy issue that many governments face in a world where capital flows are prone to bouts of enthusiasm and depression. What can be done about this problem?

We have talked about capital controls and how they can perhaps be used on a temporary basis. But then what else can be done? Fiscal policy is just not an alternative. Governments don't have fiscal policy as a button they can push. It takes time; it's hard to do. The right policy response to what is known as the capital inflow problem is still a subject of debate.

Brazil is now in its third year of not having inflation. Brazil had been a monetary alcoholic for most of its history. I as a Brazilian grew up in that environment. It really feels strange to have 5 percent inflation down there, and I think it is quite an achievement. But the achievement came with a few imbalances that naturally pose some risk of future problems.

After stabilizing and implementing an impressive array of structural reforms (trade liberalization, privatization, banking reform, etc.), Brazil finds itself in a situation where inflation is low but it has to deal with twin fiscal and current account deficits. The nominal budget deficit, though declining from the heights of the high-inflation era, remained at 6 percent of GDP in 1997 (4 percent in the operational concept, i.e., in real terms), while the current account deficit has reached about 4.3 percent of GDP. Brazil has chosen a gradual approach to handling these problems that, although not free of risks, seems feasible. The budget deficit is being gradually reduced, to the tune of 1 percent of GDP a year. Further progress depends on proposed civil service and social security reforms, both of which require constitutional amendments. To address the cur- 
rent account deficit the exchange rate is being depreciated at a rate that will generate a real devaluation of about 5 percent a year.

The gradualist approach on the fiscal and balance-of-payments fronts is likely to succeed because it is being compensated by aggressive monetary and privatization policies. The policy of very high interest rates is possible because banking sector problems were tackled early. Also, at this point there is very little leverage in the Brazilian economy. For instance, loans to the private sector add up to less than 25 percent of GDP, compared to 150 percent of GDP or so in Thailand, Malaysia, and Korea. Brazil can therefore can afford to run a very tight monetary policy for some time, at the cost of postponing a long overdue resumption of fast and sustained economic growth.

In terms of capital flows, Brazil has moved away from short-term financing. During the first year after the Real plan, Brazil was flooded with hot money. Since then the share of short-term financing of the current account has been shrinking. Already in 1996, some 50 percent of the deficit was financed by foreign direct investment and equity portfolio flows. Equities are inherently more stable because they have an automatic stabilizing factor. If investors decide to leave, prices go down, and investors change their minds. That is not the case with short-term money, which allows for exit at close to par under all but the most extreme circumstances.

On the issue of capital controls, I tend to agree with Sebastian Edwards. Capital controls may play a useful role in the short term, particularly when employed to support and reinforce good economic policies. In the long term, however, they are distortive and ineffective. Here I draw on my brief but illuminating experience at the central bank of Brazil. We spent one and a half years there trying to reduce or rationalize an extensive set of capital controls. I left the central bank convinced that long-term capital controls had harmed Brazil more than they had helped. They gave policymakers a false sense of security and probably allowed Brazil to avoid or postpone a number of important macroeconomic policy changes and structural reforms.

\section{References}

Calvo, Guillermo A., Leonardo Leiderman, and Carmen M. Reinhart. 1993. Capital inflows and real exchange rate appreciation in Latin America. IMF Staff Papers 40 (March): 108-51.

Kindleberger, Charles. 1978. Manias, panics and crashes. New York: Basic.

Marichal, Carlos. 1989. A century of debt crises in Latin America. Princeton, N.J.: Princeton University Press. 


\section{Discussion Summary}

Sebastian Edwards noted that capital controls may become a central topic of discussion at the upcoming Summit of the Americas because few disagreements remain on trade issues. He cited evidence that although capital controls have become permanent fixtures in many countries, including Chile, Colombia, and Brazil, they are largely ineffective. Edwards also drew attention to the centrality of sustainability in considering the current account deficits that are common in Latin America. For example, Chile's 4 percent current account deficit may be manageable given the size of incoming foreign direct investment flows and their productive potential.

David Folkerts-Landau noted that dismissing capital controls is equivalent to depriving countries of an instrument with which they can manage their external position. Moeen Qureshi also noted the irony that when capital flows were minimal in the 1950 s and 1960 s, the IMF recommended capital controls to countries. Now capital flows are orders of magnitude larger and the IMF is recommending the dismantling of capital controls.

Peter Garber suggested that this contradiction is resolved by noting that historically most countries had capital controls and so the policy recommendations of the IMF reflected this common practice. He inquired about the financing methods used in the privatization of banks in Mexico and about the role these methods may have played in the crisis. Garber also questioned the emphasis on short-term debt given the ability of derivatives to transform risks across the maturity spectrum. More generally, he emphasized the liquidity of the markets rather than the duration of the existing obligations.

Francisco Gil Diaz replied that there were three types of bank purchases. First, some banks were purchased by individuals who perpetrated fraud. In these banks, bad loans per se were not an issue because these banks simply became black holes. Second, some purchases were structured to minimize capital infusions leaving them highly vulnerable to losses. Third, for the two largest banks and other smaller ones, the purchases involved real capital infusion and did not involve fraud. In these cases, very poor lending decisions made them vulnerable to failure.

Folkerts-Landau noted that both Gil Diaz and Fraga minimized the role of information dissemination while the IMF had emphasized this issue in the months following the crisis. He concurred with the speakers that aggregate data were available but questioned whether detailed data allowing investors to understand the financial exposure of the system were available in a timely fashion in the cases of Mexico and Thailand. Martin Feldstein also questioned Fraga about the information advantages that might lead certain speculators to behave more aggressively in foreign exchange markets.

Gil Diaz suggested that the relevant information on the banking system and reserve position in Mexico was available but went unheeded. While Arminio Fraga agreed with the general emphasis of the IMF on improved information 
disclosure, he concurred with Gil Diaz that the Mexican situation was one where enough information was available either through public disclosure or through informal channels.

Paul Krugman noted that the emphasis on certain statistics, such as current account deficits, leads to inappropriate conclusions without consideration of the investment opportunities within a country. He recalled a quote from James Callahan, a former chancellor of the exchequer for the United Kingdom, who suggested that the absence of statistics had allowed the British to emerge from previous crises unscathed. Feldstein countered that presumably a country runs out of reserves at some point. Krugman replied that, nonetheless, the emphasis on statistics may obscure underlying subtleties to an economic situation.

David Mullins noted that all central bankers would appreciate this call for opaqueness. Qureshi supported Krugman's point that certain types of information are being emphasized at the expense of a subtler understanding of the larger economic situation. He referred to the recent emphasis on the strength of the financial sector, for example, and questioned how fundamental this is to a country's prospects. Gil Diaz recalled that Milton Friedman had suggested that current account figures not be published. Krugman responded to this comparison by retracting his initial suggestion.

Andrew Crockett suggested that currency boards or flexible exchange rates provide for more stability than fixed exchange rates. He emphasized, however, that linkages created by common trade areas, such as Mercosur, could create spillovers when exchange rate regimes are distinct. Thus, the question of the optimal strategy within trade zones that feature distinct exchange rate regimes is extremely important. Feldstein noted that these problems are common to all countries pursuing stable relations with their trading partners. Gil Diaz agreed that flexible exchange rates, while superior to fixed regimes, are no vaccine against crisis and that no system can resist a speculative attack given the linkages in the world economy through trade and capital flows.

In contrast to Fraga's conclusions about Brazil, Edwards expressed concern about its short-term debt position. He suggested that massive increases in reserves would be needed over the next several years for Brazil to emerge unscathed. Mullins noted that if privatization proceeds are required for Brazil to emerge from its current predicament, its prospects are tightly linked to the future of the U.S. equity market. Finally, Garber noted that in the Brazilian case, some foreign direct investment was used to disguise short-term inflows as firms circumvented capital controls by buying small firms and purchasing commercial paper.

Fraga agreed that there exists little room for error in Brazil's situation. However, he suggested that the gradual process of annual 5 percent real devaluation now under way could prove successful. He also noted that much of the remaining short-term debt is domestic and that much of the short-term foreign money has already left Brazil. Fraga was therefore cautiously optimistic about 
Brazil's prospects for emerging from its current difficulties without a severe discontinuity.

Edwards suggested that political events were more central to the Mexican crisis than were Federal Reserve actions. Fed tightening began in February 1994, suggesting large and unreasonable lags for it to have played a large role in the crisis. Similarly, Mullins noted, the recent Asian crisis featured a very benign backdrop of low interest rates and a booming stock market. In a similar vein, Feldstein noted that while steep increases in U.S. interest rates in the early 1980s may have had an important effect around the world, he disagreed that the gradual tightening of 1994 could have had such a dramatic effect. Instead, he highlighted the political events and the current account situation for the Mexican crisis.

Gil Diaz suggested that large changes in the long end of the term structure in the United States were premonitory of tightening and that these effects were felt immediately in Mexico. More generally, he agreed that political factors were most important and interest rate changes were secondary. 
This Page Intentionally Left Blank 